\title{
Negative Regulation of Lung Inflammation and Immunopathology by TNF- $\alpha$ during Acute Influenza Infection
}

\author{
Daniela Damjanovic, ${ }^{*}$ Maziar Divangahi, ${ }^{*}$ \\ Kapilan Kugathasan, ${ }^{*}$ Cherrie-Lee Small, ${ }^{*}$ \\ Anna Zganiacz, ${ }^{*}$ Earl G. Brown, ${ }^{\dagger}$ \\ Cory M. Hogaboam, ${ }^{\ddagger}$ Jack Gauldie, ${ }^{*}$ and \\ Zhou Xing* \\ From the Department of Pathology and Molecular Medicine $\mathcal{E}$ \\ McMaster Immunology Research Centre,* McMaster University, \\ Hamilton, Ontario, Canada; the Department of Microbiology \\ and Immunology, ${ }^{\dagger}$ Faculty of Medicine, University of Ottawa, \\ Ottawa, Ontario, Canada; and the Department of Pathology, \\ University of Michigan Medical School, Ann Arbor, Michigan
}

Lung immunopathology is the main cause of influenzamediated morbidity and death, and much of its molecular mechanisms remain unclear. Whereas tumor necrosis factor- $\alpha$ (TNF- $\alpha$ ) is traditionally considered a proinflammatory cytokine, its role in influenza immunopathology is unresolved. We have investigated this issue by using a model of acute H1N1 influenza infection established in wild-type and TNF- $\alpha$ deficient mice and evaluated lung viral clearance, inflammatory responses, and immunopathology. Whereas TNF- $\alpha$ was up-regulated in the lung after influenza infection, it was not required for normal influenza viral clearance. However, TNF- $\alpha$ deficiency led not only to a greater extent of illness but also to heightened lung immunopathology and tissue remodeling. The severe lung immunopathology was associated with increased inflammatory cell infiltration, anti-influenza adaptive immune responses, and expression of cytokines such as monocyte chemoattractant protein-1 (MCP-1) and fibrotic growth factor, TGF- $\beta 1$. Thus, in vivo neutralization of MCP-1 markedly attenuated lung immunopathology and blunted TGF- $\beta 1$ production following influenza infection in these hosts. On the other hand, in vivo transgenic expression of MCP-1 worsened lung immunopathology following influenza infection in wild-type hosts. Thus, TNF- $\alpha$ is dispensable for influenza clearance; however, different from the traditional belief, this cytokine is critically required for negatively regulat- ing the extent of lung immunopathology during acute influenza infection. (Am J Pathol 2011, 179:2963-2976; DOI: 10.1016/j.ajpath.2011.09.003)

Pulmonary influenza is a common and highly contagious respiratory infectious disease. Annual influenza epidemics account for significant morbidity and mortality worldwide. The 1918 influenza pandemic killed 50 million people worldwide, and emerging strains such as the novel swine-origin influenza $A(H 1 N 1)$ virus pose a continuing threat to the world. ${ }^{1,2}$ It is now well established that lung immunopathology is one of the main causes of influenzarelated morbidity and mortality. ${ }^{3-11}$

Influenza viruses are negative-stranded, enveloped RNA viruses belonging to the family Orthomyxoviridae that preferentially infect and replicate in bronchial epithelial cells. ${ }^{7}$ Both innate and adaptive immune responses are key players in the host defense against influenza. ${ }^{8,9,12-14}$ Part of such host immune responses involves the production of antiviral and inflammatory cytokines and chemokines from infected airway epithelial cells and leukocytes, including interferon (IFN)- $\alpha / \beta$, TNF- $\alpha$, IFN- $\gamma$, keratinocytederived chemokine (KC), monocyte chemoattractant protein-1 (MCP-1), macrophage inflammatory protein-1 (MIP-1) $\alpha / \beta$, MIP-3 $\alpha$, interferon- $\gamma$ inducible protein 10 (IP$10)$, and regulated on activation normal T-cell expressed and secreted (RANTES). ${ }^{9,15-17}$ Cytotoxic CD8 T cells play an important role in influenza viral clearance by lysing virus-infected cells, and effective viral clearance from the lung is usually achieved within 7 to 10 days after primary infection. ${ }^{8,12,13} \mathrm{~A}$ strong CD4 T-helper response is believed to contribute to the generation of robust hu-

Supported by funds from the Ontario Thoracic Society and the Canadian Institutes for Health Research.

Accepted for publication September 1, 2011

Supplemental material for this article can be found at http://ajp. amjpathol.org or at doi: 10.1016/j.ajpath.2011.09.003.

Address reprint requests to Zhou Xing, M.D., Ph.D., Rm. 4012-MDCL, Department of Pathology \& Molecular Medicine, McMaster University, 1280 Main Street West, Hamilton, Ontario L8S 4K1, Canada. E-mail: xingz@mcmaster.ca. 
moral responses, important for neutralization of the virus. ${ }^{8,12,13}$ Although these host immune responses are critical to influenza viral clearance, they often cause undesired lung immunopathology, severe cases of which may also develop irreversible tissue injury and fibrotic remodeling. ${ }^{7-10,18-20}$ Much of the immunoregulatory mechanisms of influenza immunopathology and tissue injury still remain to be understood.

Members of the TNF superfamily are critically involved in the maintenance of homeostasis of the immune system and have many pleiotropic effects such as proliferation, survival, differentiation, or apoptosis of responding cells. ${ }^{21,22}$ TNF- $\alpha$ is traditionally considered as a proinflammatory and proimmune cytokine. ${ }^{21,22}$ Indeed, there is evidence to suggest its proimmune role at several early points of host defense against influenza infection. ${ }^{23-27}$ In this regard, the limited data also suggest that production of TNF- $\alpha$ by influenza-specific CD8 T cells may contribute to lung immunopathology. ${ }^{28,29}$ The immune-activating role of TNF- $\alpha$ was also shown in the models of other viral infections. ${ }^{30,31}$ However, recent emerging evidence has suggested an immune regulatory nature of TNF- $\alpha$. It has been shown that TNF- $\alpha$ is required for controlling the level of Th1 cell activation and immunopathology following pulmonary mycobacterial infection. ${ }^{32}$ Furthermore, TNF- $\alpha$ was found to negatively regulate CD4 and CD8 T-cell responses to lymphocytic choriomeningitis virus (LCMV) infection. ${ }^{33-35}$ In support of its immune regulatory role in anti-infection host defense, neutralization of TNF- $\alpha$ has also been found to worsen the severity of a number of autoimmune conditions in humans with multiple sclerosis and in models of experimental autoimmune encephalomyelitis and lupus. ${ }^{21,36-39}$ Of interest, treatment of rheumatoid arthritis patients with etanercept, a soluble TNF- $\alpha$ receptor, led to increased peripheral T-cell reactivity both to microbial antigens such as influenza and to tissue antigens such as collagen type $11^{40}$ Recent evidence has also implicated an antifibrotic activity of TNF- $\alpha$ in models of idiopathic pulmonary fibrosis, ureteral obstruction, and scleroderma. ${ }^{41-43}$ However, whether TNF- $\alpha$ plays an immunoregulatory role in host defense and immunopathology during influenza infection still remains poorly understood.

In our current study, we have used a murine model of acute respiratory influenza $A$ infection to investigate the immunoregulatory role of TNF- $\alpha$ in viral clearance, host immune responses, and lung immunopathology. For the first time, our study demonstrates that TNF- $\alpha$ is not required for effective influenza viral clearance in the lung, but it is critically required for controlling the extent of lung immunopathology. Such heightened immunopathology in the animals lacking TNF- $\alpha$ is linked to markedly increased inflammatory cellular infiltration and cytokine responses. Thus, selective inhibition of up-regulated chemokine MCP-1 in these animals dampens lung immunopathology. On the other hand, overexpression of MCP-1 in the lung of infected wild-type animals worsens immunopathology. These findings suggest that different from the conventional belief, TNF- $\alpha$ is a critical negative regulator of inflammatory responses and immunopathology in the lung during acute influenza infection.

\section{Materials and Methods}

\section{Mice}

Male 7- to 10-week-old C57BL/6 mice were purchased from Harlan Laboratories (Indianapolis, IN). TNF- $\alpha$ knockout $\left(\mathrm{TNF}^{-1-}\right)$ breeding pairs on a C57BL/6 background were purchased from The Jackson Laboratory (Bar Harbor, ME) and were bred in the barrier at the McMaster University Central Animal Facility (Hamilton, ON, Canada). Mice were housed in specific pathogen-free-level facilities. For all experiments, mice were euthanized by exsanguination of the abdominal artery under anesthesia. All experiments were conducted in accordance with the animal research ethics board of McMaster University.

\section{Pulmonary Influenza Infection}

The virus strain used in the studies was a mouse-adapted strain of influenza A/FM/1/47 $(\mathrm{H} 1 \mathrm{~N} 1)^{44}$, prepared and used as previously described. ${ }^{45}$ Mice anesthetized by inhalation of isoflurane were infected with $2 \times 10^{4}$ plaque forming units of influenza virus in $20 \mu \mathrm{L}$ of PBS, intranasally. Body weight was measured at various times after infection.

\section{Viral Titer Determination}

At 3,7 , and 14 days after infection, lungs were homogenized in PBS and centrifuged for 10 minutes at $800 \times 9$ at $4^{\circ} \mathrm{C}$. Serial dilutions of the supernatants were applied to a confluent monolayer of Madin-Darby canine kidney (MDCK) cells, as previously described. ${ }^{46}$ Briefly, an enriched agarose medium (1\% agarose, $2 \times \mathrm{F}-11$ minimal essential medium, $2 \%$ L-glutamine, $2 \%$ penicillin-streptomycin, and $5 \mathrm{mg} / \mathrm{mL}$ trypsin) was added to the infected cells after 30 minutes at $37^{\circ} \mathrm{C}$, and then incubated at $37^{\circ} \mathrm{C}$ for 2 days. The cells were fixed with Carnoy's fixative (25\% acetic acid and $75 \%$ methanol), and plaques counted.

\section{Pulmonary Histopathological and Morphometric Analysis}

Lungs were inflated with $10 \%$ formalin and then kept in 5 $\mathrm{mL}$ of $10 \%$ formalin for at least 72 hours. Tissue sections were stained with hematoxylin and eosin (H\&E) for conventional histopathological examination or with Masson's trichrome for collagen deposition. Immunohistochemistry for the myofibroblast marker $\alpha$-smooth muscle actin $(\alpha-$ SMA) was performed on deparaffinized lung tissue sections using the ARK (Animal Research Kit) Peroxidase kit, according to the manufacturer's protocol (Dako, Glostrup, Denmark). ${ }^{47}$ Blinded lung histopathology scoring was performed by using a semiquantitative method ranging from 0 to 5 , with 5 being the most extensive pathology. Morphometric analysis was performed by blinded observers to quantify the extent of immunopathological and fibrotic responses with the Northern Eclipse Image Analysis Software (Empix Imaging, Mississauga, ON, Canada). 


\section{Bronchoalveolar Lavage and Differential Cell Counting}

Airway luminal cells were collected by bronchoalveolar lavage (BAL) of the lungs by using a standard procedure previously described. ${ }^{32,48}$ Lungs were lavaged twice with $250 \mu \mathrm{L}$ and $200 \mu \mathrm{L}$ of PBS and then centrifuged. BAL fluids were stored at $-20^{\circ} \mathrm{C}$ until antibody and cytokine measurement. Cell pellets were combined with cells from lavages of $900 \mu \mathrm{L}$ of PBS in total, and resuspended in $800 \mu \mathrm{L}$ of complete RPMI medium (RPMI 1640 supplemented with 10\% FBS, 1\% penicillin-streptomycin, and $1 \%$ L-glutamine). Differential cell counts were determined using cytocentrifuged specimens prepared from $10^{5}$ cells stained with a modified Wright-Giemsa stain solution (Polysciences, Warrington, PA). The cells were classified according to standard morphological criteria as alveolar macrophages, polymorphonuclear cells, and lymphocytes.

\section{Lung Cell Isolation}

Mononuclear cells were isolated from lung tissue, as previously described. ${ }^{45}$ Briefly, the lungs were cut into small pieces and incubated in $10 \mathrm{~mL}$ of $150 \mathrm{U} / \mathrm{mL}$ collagenase type I (Sigma-Aldrich, St. Louis, MO) for 1 hour at $37^{\circ} \mathrm{C}$, with agitation. The lung pieces were then crushed through 40- $\mu \mathrm{m}$ basket filters, red blood cells lysed with ACK lysis buffer $\left[0.15 \mathrm{~mol} / \mathrm{L} \mathrm{NH}_{4} \mathrm{Cl}, 1 \mathrm{~mol} / \mathrm{L}_{\mathrm{KHCO}_{3}}, 0.1\right.$ $\mathrm{mmol} / \mathrm{L} \mathrm{Na} \mathrm{NDTA}_{2}$ ( $\mathrm{pH}$ 7.4)], and the remaining lung cells resuspended in complete RPMI.

\section{Flow Cytometric Analysis}

Fluorescence-activated cell sorting and intracellular cytokine staining were performed on BAL and lung cells. For intracellular cytokine staining, BD GolgiPlug (protein transport inhibitor containing Brefeldin A) (BD Biosciences, San Jose, CA) was added to ex vivo cultures stimulated with the nucleoprotein (NP) $)^{366-374}$ or NS2 $2^{114-121}$ influenza peptides for 5 to 6 hours. Cells were subsequently blocked for 15 minutes with the CD16/CD32 Fc block antibody, and then stained with the extracellular antibodies Pacific Blue anti-CD3, APC-Alexa Fluor 750 anti-CD4, and PECy7 anti-CD8 (BD Biosciences). Cells were then fixed and permeabilized according to the manufacturer's protocol using the BD Cytofix/Cytoperm solutions (BD Biosciences), and subsequently stained with the intracellular antibody APC anti-IFN- $\gamma$ (BD Biosciences). Alternatively, unstimulated cells were first stained with PE-DbNP366 tetramers ( $\mathrm{MHC}$ I; specific to the influenza NP ${ }^{366}$ epitope) (Baylor College of Medicine, Houston, TX) and then with the extracellular antibodies mentioned above. For antigen-presenting cell staining, the extracellular antibodies APC anti-CD11c and PECy7 anti-CD11b (BD Biosciences) were used. Stained cells were run on the LSRII flow cytometer (BD Biosciences) and analyzed using FlowJo software (Tree Star, Ashland, OR).

\section{Influenza-Specific Antibody ELISA}

Levels of anti-influenza antibodies in the BAL fluid and blood serum were measured by ELISA using a modified protocol. ${ }^{49}$ Ninety-six-well ELISA plates (Nalge Nunc International, Rochester, NY) were coated with $2.5 \mu \mathrm{g}$ per well of influenza-infected MDCK cell lysate and incubated at $4^{\circ} \mathrm{C}$ overnight. Wells were then blocked with Blocking buffer (1\% bovine serum albumin in PBS) for 1 hour at $37^{\circ} \mathrm{C}$. Samples diluted in dilution buffer $(0.3 \%$ bovine serum albumin in PBS) were added to the wells and incubated for 1 hour at $37^{\circ} \mathrm{C}$. Goat anti-mouse IgG1biotin or IgG2a-biotin (Southern Biotechnology Associates, Birmingham, AL) or IgA-biotin conjugates (SigmaAldrich) were added and incubated for 1 hour at $37^{\circ} \mathrm{C}$, followed by streptavidin conjugated alkaline phosphatase (R\&D Systems, Minneapolis, MN) for 1 hour at $37^{\circ} \mathrm{C}$. As a substrate, a p-nitrophenyl phosphate tablet (SigmaAldrich) was dissolved in $5 \mathrm{~mL}$ of $10 \%$ diethanolamine [50 g diethanolamine, $0.1 \mathrm{~g} \mathrm{NaN}_{3}, 0.05 \mathrm{~g} \mathrm{MgCl}_{2} .6 \mathrm{H}_{2} \mathrm{O}$ in $500 \mathrm{~mL}$ distilled water ( $\mathrm{pH}$ 9.8)], $50 \mu \mathrm{L}$ were added to each well, and incubated at room temperature for 15 to 30 minutes in the dark. The reaction was then stopped with $25 \mu \mathrm{L}$ of $2 \mathrm{~N} \mathrm{NaOH}$ per well, and the colorimetric change was evaluated with a microplate reader at 405 $\mathrm{nm}$. The titer was calculated as: antibody titer = (sample dilution factor $\times \mathrm{OD}_{405}$ reading)/0.05, where $\mathrm{OD}_{405}$ is the optical density at $405 \mathrm{~nm}$.

\section{Cytokine and Chemokine Quantification}

Levels of cytokines and chemokines in BAL fluid and lung homogenates were quantified using DuoSet ELISA Development Kits (R\&D Systems) or using Luminex multianalyte technology (Luminex Molecular Diagnostics, Toronto, ON, Canada), according to the manufacturer's protocols.

\section{In Vivo Cytokine/Chemokine Neutralization and Gene Transfer}

For MCP-1 neutralization experiments, rabbit anti-murine MCP-1 serum or normal rabbit serum as control (200 $\mu \mathrm{L}$ /injection) was injected intraperitoneally into influenzainfected $T N F^{-1-}$ mice at 2, 5, and 9 days after infection. For MCP-1 overexpression experiments, a replication-deficient adenoviral gene transfer vector expressing murine MCP-1 (AdMCP-1) or an empty adenoviral vector (Addl) as a control were used. ${ }^{50}$ Wild-type (WT) mice were infected intranasally with $2 \times 10^{8}$ plaque forming units of AdMCP-1 or Addl, and were infected with influenza the next day. For TNF- $\alpha$ neutralization experiments, rabbit anti-murine TNF- $\alpha$ serum or normal rabbit serum as control (200 $\mu \mathrm{L} /$ injection) was injected intraperitoneally into influenza-infected WT mice on days $-1,2,5,8$, and 12 after infection.

\section{Statistical Analysis}

To determine whether the differences among infection groups were significant, Student's t-test was used for two-sample comparisons. For comparison between more than two groups, one-way analysis of variance and Tukey's 
post hoc test were performed with Prism (GraphPad Software, Inc., La Jolla, CA). A $P$ value of $<0.05$ was regarded as statistically significant.

\section{Results}

TNF- $\alpha$ Is Increased in the Lung but Is Not Required for Viral Clearance during Primary Influenza Infection

Following respiratory infection with a nonlethal dose of influenza A virus, TNF- $\alpha$ was up-regulated between days 3 and 14 in the lungs of wild-type C57BL/6 mice (see Supplemental Figure S1 at http://ajp.amjpathol.org). To determine the role of TNF- $\alpha$ in influenza viral clearance, WT and TNF- $\alpha$-deficient $\left(T N F^{-1-}\right.$ ) mice were infected with influenza virus, and body weight changes were monitored as a measure of sickness and disease recovery. For WT mice, body weight was stable during the period of acute infection ( 1 to 7 days after infection) and then began to steadily increase from day 7 onward (Figure $1 \mathrm{~A})$. On the other hand, $T N F^{-/-}$mice lost weight between days 5 and 10 (Figure 1A). After day 10, although $T N F^{-1-}$ mice began to regain weight, their body weight status remained well below that in WT controls until day 30 after infection (Figure 1A). These data suggest that the infected animals lacking TNF- $\alpha$ suffered a certain degree of illness from an otherwise nonlethal, small dose of influenza infection.

To examine whether the greater illness seen in infected $T N^{-1-}$ mice was due to dysregulated influenza viral clearance, viral titers in the lungs were examined by a plaque formation assay. We detected a high, but comparable, level of influenza viral titers in the lung of WT and $T N F^{-1-}$ mice at 3 days after infection (Figure 1B). By day 7 , the viral titers drastically declined in the lungs of both WT and $T N F^{-1-}$ mice, and by day 14 , the infection was completely cleared (Figure 1B). These results suggest that $T N F^{-1-}$ mice were able to clear influenza virus from the lungs equally well as WT controls and that the illness seen with these mice was not due to delayed or uncontrolled influenza viral infection in the lung.

\section{Sustained Lung Immunopathology in TNF- $\alpha-$ Deficient Hosts after Influenza Infection}

To understand the cause of illness in $\mathrm{TNF}^{-1-}$ hosts, we assessed histopathology in the lung. At 3 days after infection, when viruses could be easily detected in the lungs (Figure 1B), peribronchial inflammation characterized by a mononuclear cell infiltrate in the interstitial space surrounding the airways and blood vessels was observed in both strains of mice, whereas a greater extent of inflammatory infiltration in the bronchial epithelium was seen in $T N F^{-1-}$ lungs (data not shown). By 7 days after infection, when few viruses could be detected in the lungs of WT and $\mathrm{TNF}^{-\prime-}$ mice (Figure 1B), WT mouse lungs had only mild remaining inflammatory infiltration in the peribronchial region, but in contrast, the lungs of the $\mathrm{TNF}^{-1-}$ counterparts displayed severe mononuclear in-
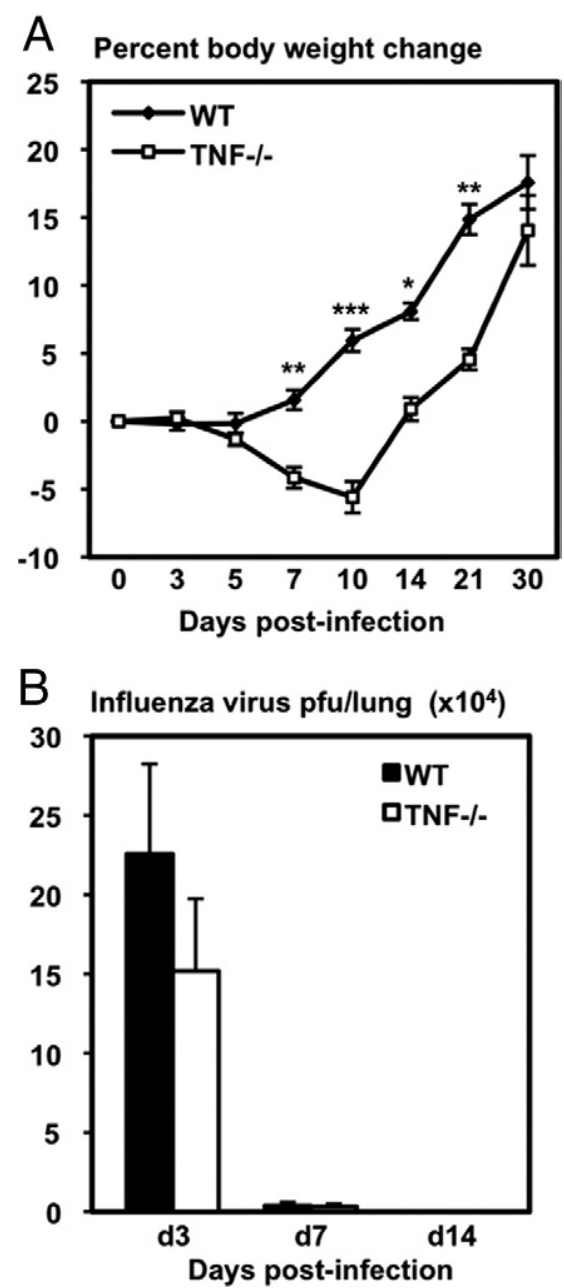

Figure 1. TNF- $\alpha$ is not required for influenza viral clearance in the lung. WT and $T N F^{-1}$ mice were intranasally infected with influenza virus. A: Average percent body weight change of WT ( $n=28 /$ time point $)$ and $T N F^{-1}(n=$ $85 /$ time point) mice was monitored. Results are from multiple independent experiments. B: At day 3, 7, and 14 after infection, the viral titer in the lung was evaluated by plaque forming assay ( $n=4$ to $8 /$ strain/time point from two independent experiments). Data are expressed as mean \pm SEM. ${ }^{*} P<$ $0.05,{ }^{* *} P<0.01$, and ${ }^{* * * *} P<0.001$ as compared to WT controls.

filtration in the peribronchial and perivascular regions and bronchial hyperplasia (Figure 2, A and B; Table 1). After the infection was completely cleared in the lung from 14 days on (Figure 1B), the lungs of WT mice appeared largely clear and returned to normal at days 14 , 21, and 30 (Figure 2, C, E, and G; Table 1). In contrast, $T N^{-\prime-}$ lungs showed worsened inflammatory infiltration and extensive bronchial epithelium injury and sloughing (Figure 2D; Table 1). By day 21, immunopathology in

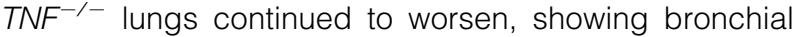
and alveolar structural injury, hemorrhage, metaplasia, and numerous dense cellular aggregates characteristic of fibrotic tissue remodeling (Figure 2F; Table 1). At day 30 after infection, although $T N F^{-1-}$ lungs had reduced inflammatory infiltration, there still existed significant bronchial epithelial hyperplasia and fibrotic cellular aggregates (Figure $2 \mathrm{H}$; Table 1).

To further dissect the fibrotic tissue remodeling in the lung of $\mathrm{TNF}^{-1-}$ mice, we examined lung samples col- 

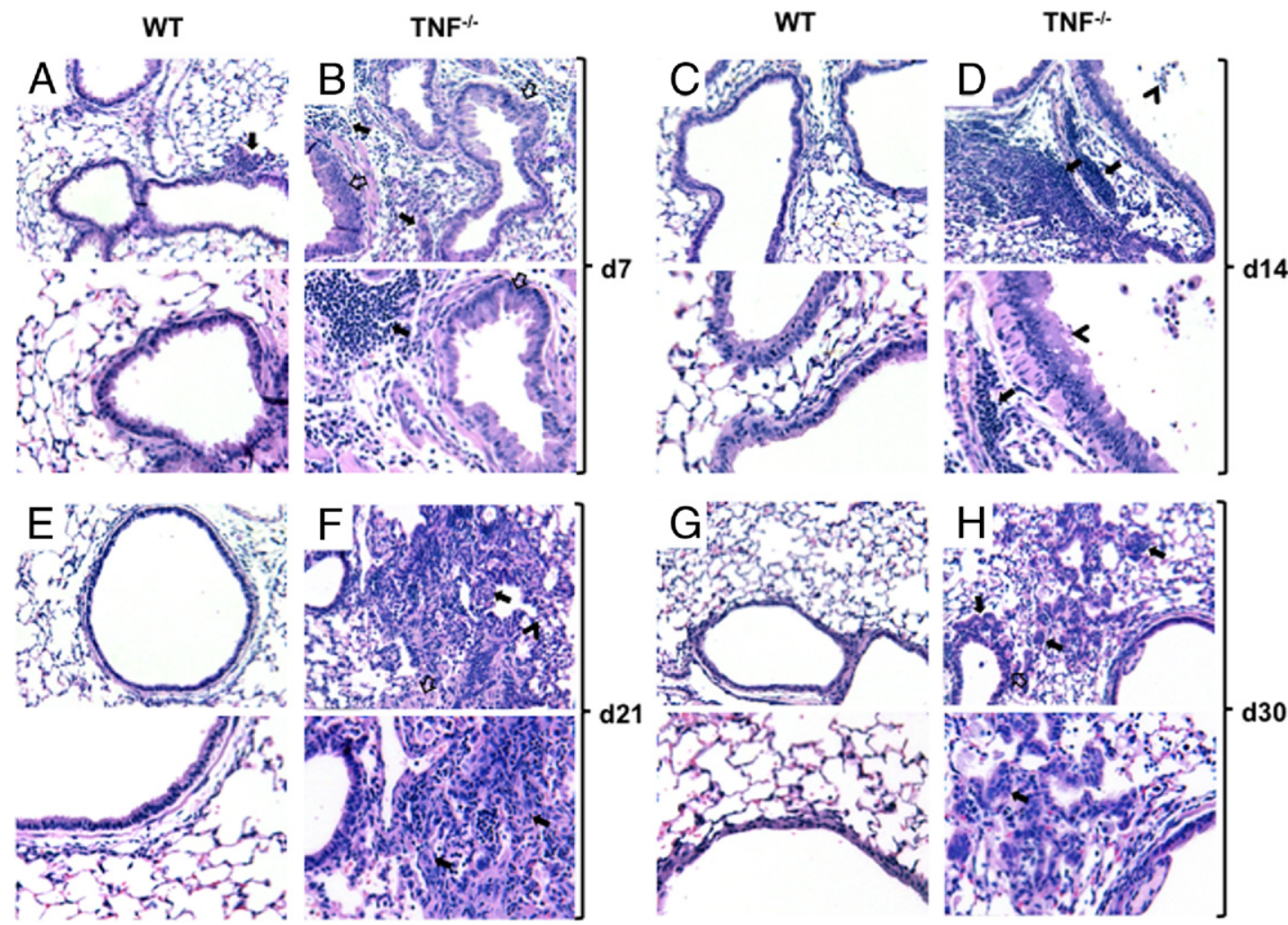

Figure 2. Immunopathological changes in the lungs following influenza infection. Mice were sacrificed 7, 14, 21, and 30 days after influenza infection, and lung tissue sections were stained with H\&E. Representative slides are shown at $\times 5$ (top) and $\times 10$ (bottom) original magnification. A, C, E, and G: WT mice exhibited transient lung inflammation. B, D, F, and $\mathbf{H}: T N F^{-1-}$ mice showed persistent lung immunopathology and injury. A, B, and $\mathbf{D}$ : Mononuclear infiltration (closed arrow). B and H: Bronchial hyperplasia (open arrow). D: Bronchial epithelium injury and sloughing (arrowhead). F: Structural injury (arrowhead), metaplasia (open arrow). $\mathbf{F}$ and $\mathbf{H}$ : Fibrotic cellular aggregates (closed arrow).

lected at days 14 and 21, using Masson's trichrome staining and immunohistochemical staining for $\alpha$-SMA. $\alpha$-SMA is highly expressed by collagen-releasing myofibroblasts, the key cellular component of fibrosis. ${ }^{51,52}$ There was a lack of any signs of pulmonary fibrotic reaction in influenza-infected WT lungs at any time point after influenza infection (Figure 3, A, B, C, and D; Table 1). However, infected $T N F^{-/-}$lungs had overt signs of fibrotic tissue remodeling at days 14 and 21 (Table 1), including increased extracellular collagen deposition in lung parenchyma (Figure $3, A$ and $C$ ), the appearance of myofibroblasts (Figure 3, B and D), and the formation of fibrotic foci with abundant collagen deposition and myofibroblast accumulation (Figure 3E). Furthermore, by using the Sirius Red colorimetric assay (Sircol collagen assay), we measured the total collagen content and found that at day 21 after infection, $\mathrm{TNF}^{-1-}$ mouse lungs had more collagen than WT lungs (data not shown). The above results together indicate that the illness observed in influenza-infected TNF- $\alpha$-deficient hosts was due to sustained severe lung immunopathology and tissue remodeling.

\section{Markedly Increased Inflammatory Cellular Responses in the Lung of TNF- $\alpha$-Deficient Hosts after Influenza Infection}

To begin examining the mechanisms of pronounced immunopathology and tissue remodeling in the lung of in-

Table 1. Assessment of Histopathological Changes in the Lung

\begin{tabular}{|c|c|c|c|c|c|c|c|c|}
\hline & \multicolumn{2}{|c|}{ Day 7} & \multicolumn{2}{|c|}{ Day 14} & \multicolumn{2}{|c|}{ Day 21} & \multicolumn{2}{|c|}{ Day 30} \\
\hline & WT & $T N F^{-1-}$ & WT & $T N F^{-1-}$ & WT & $T N F^{-1-}$ & WT & $T N F^{-1-}$ \\
\hline Inflammation & + & ++ & $+1-$ & +++ & - & +++ & - & ++ \\
\hline Injury & + & ++ & + & +++ & $+1-$ & ++++ & - & +++ \\
\hline Remodeling & - & - & - & ++ & - & +++ & - & +++ \\
\hline
\end{tabular}

Lung inflammation (mononuclear cell infiltration), lung injury (degeneration of airway epithelium, necrosis, bronchoepithelial hyperplasia, metaplasia in the lung parenchyma, hemorrhaging), and tissue remodeling (pulmonary fibrosis: myofibroblasts, collagen deposition, scarring, fibrotic foci) were assessed.

Results are representative of $n=8$ to 12/strain/time point from two to three independent experiments.

- , absent; + , minimal; ++ , slight; +++ , moderate; ++++ , marked; +++++ , severe 

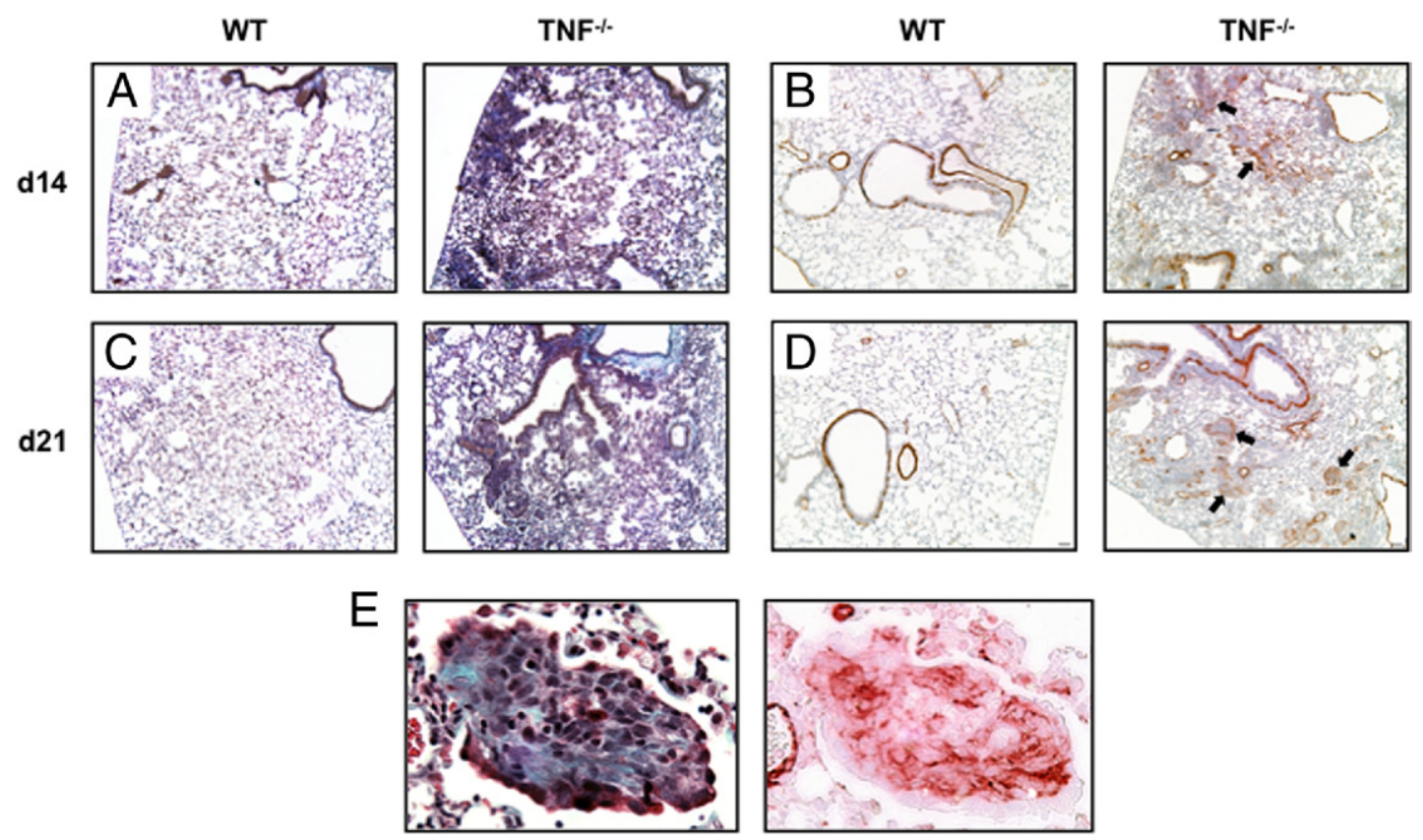

Figure 3. Tissue fibrotic remodeling in the lungs of $T N F^{-1}$ mice following influenza infection. WT and $T N F^{-1}$ mice were sacrificed 14 and 21 days after influenza infection. A and C: Lung tissue sections were stained with Masson's trichrome that stains collagen fibers blue. B and D: Lung sections were immunohistochemically stained using a monoclonal antibody against $\alpha$-SMA found on myofibroblasts in fibrotic foci, which stains brown-red (arrows). Representative images are shown at $\times 5$ original magnification. E: Representative fibrotic foci stained with Masson's trichrome (left) or for $\alpha$-SMA in $T N F^{-1}$ (right) lungs at 21 days after infection are shown at $\times 40$ original magnification.

fluenza-infected $T N F^{-1-}$ mice, we first evaluated the types of inflammatory cell infiltrates in the respiratory tract. To this end, BAL was performed on infected WT and $T N F^{-1-}$ mice, and leukocytes were differentiated on cytospins. In the lung of WT mice, the number of inflammatory cells, including alveolar macrophages, neutrophils, and lymphocytes, steadily declined from day 7 until day 30 , the last time point examined (Figure 4, A, B, and C), which coincided well with a marked drop in viral titers by day 7 and a complete viral clearance by day 14 (Figure 1B). On the contrary, compared to WT controls
$\mathrm{TNF}^{-1-}$ mouse lungs had significantly greater numbers of alveolar macrophages, neutrophils, and lymphocytes at all time points examined (Figure 4, A, B, and C). Of note, whereas the overall numbers of macrophages and neutrophils decreased over time in the lung of $\mathrm{TNF}^{-\prime-}$ mice, the number of lymphocytes was somewhat sustained between days 14 and 30 (Figure 4, A, B, and C). These data suggest that severe immunopathology and tissue remodeling in infected $T N F^{-/-}$hosts are linked to an exaggerated inflammatory cellular response in the lung.
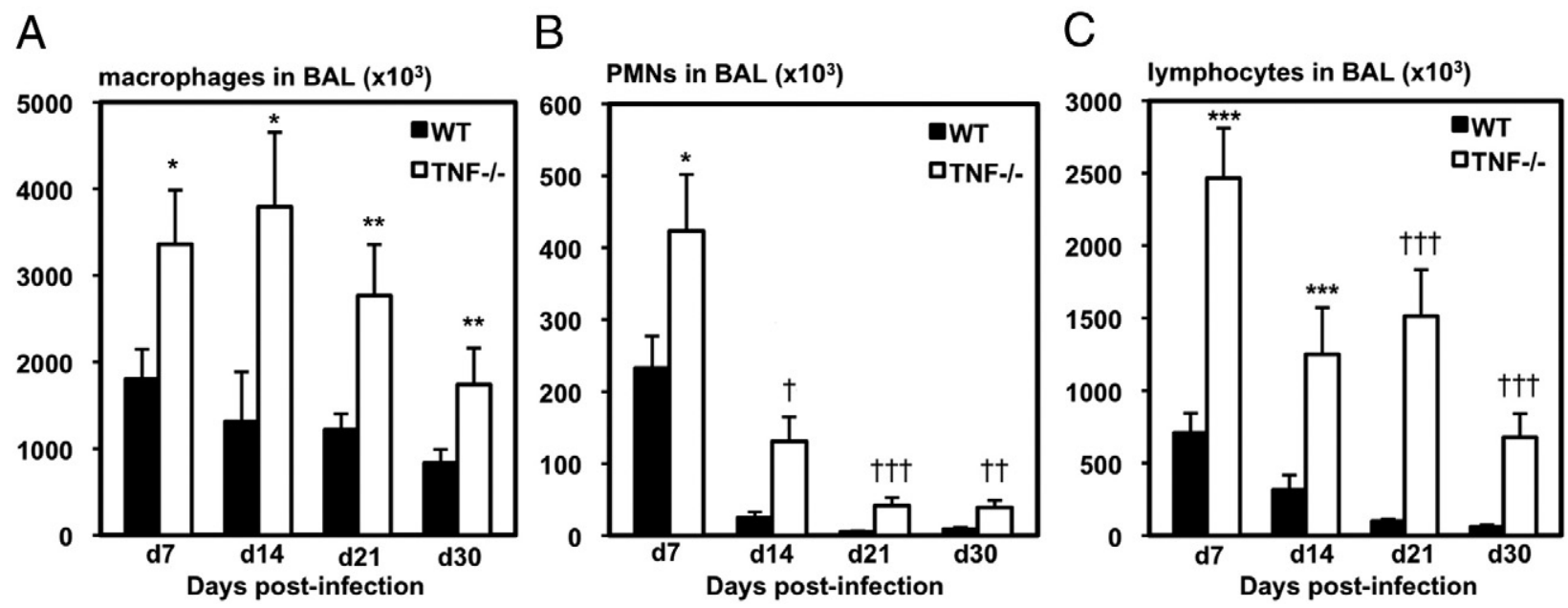

Figure 4. Inflammatory cellular infiltration in the lungs following influenza infection. WT and TNF ${ }^{/}-$mice were sacrificed $7,14,21$, and 30 days after influenza infection, and differential cell counting was performed on cytospins of bronchoalveolar lavages. Alveolar macrophages (A), polymorphonuclear cells (PMNs) (B), and lymphocytes $(\mathbf{C})$ were enumerated. Results are expressed as mean \pm SEM ( $n=8$ to $12 /$ strain/time point from two to three independent experiments). ${ }^{*} P<0.05,{ }^{* *} P<0.01,{ }^{* * *} P<0.005,{ }^{\dagger} P<0.0005,{ }^{t} P<0.00005$, and ${ }^{{ }^{*}} P P<0.0000005$ as compared to WT. 


\section{Markedly Increased Influenza-Specific Adaptive Immune Responses in the Lung of TNF- $\alpha$-Deficient Hosts after Influenza Infection}

Antigen-specific CD8 T-cell responses play an important role in anti-influenza host defense. . $^{8,12,13}$ Thus, by using influenza NP366-374 (H-2Db) tetramer immunostaining and intracellular cytokine staining techniques, we further examined the properties of markedly increased total lymphocytes seen in the lung of infected $\mathrm{TNF}^{-1-}$ mice (Figure $4 \mathrm{C}$ ). $\mathrm{TNF}^{-1-}$ mice had more total $\mathrm{CD}^{+} \mathrm{CD}^{+}$and $\mathrm{CD} 3^{+} \mathrm{CD} 4^{+} \mathrm{T}$ cells than WT mice, both in the BAL (airway lumen) and lung interstitium at all time points after infection (days 7 to 30) (data not shown). On tetramer immunostaining, there were much greater frequencies and numbers of NP-specific tetramer ${ }^{+} \mathrm{CD}^{+}{ }^{+} \mathrm{T}$ cells in the $\mathrm{BAL}$ and lung of $\mathrm{TNF}^{-1-}$ mice over the entire course of infection examined (days 7 to 30) compared to WT mice (Figure 5, A and B). Furthermore, on NP peptide stimulation ex vivo, there were also significantly higher frequencies and numbers of IFN- $\gamma^{+} \mathrm{CD} 8^{+} \mathrm{T}$ cells in the BAL and lung of $T N F^{-\prime-}$ mice at various time points after infection, compared to WT (Figure 5, C and D). Similar results were obtained with NS2 ${ }^{114-121}$ peptide stimulation (data not shown). These results indicate that TNF- $\alpha$ deficiency does not impede adaptive T-cell responses to primary influenza infection.

As B-cell-mediated antibody responses also play a role in anti-influenza host defense, $8,13,14$ and given the observed heightened influenza antigen-specific T-cell responses, we next examined the level of influenza-specific antibody responses, both in the BAL (airway lumen) and the peripheral blood, by ELISA. We found that the levels of influenza-specific IgA were slightly higher at 14
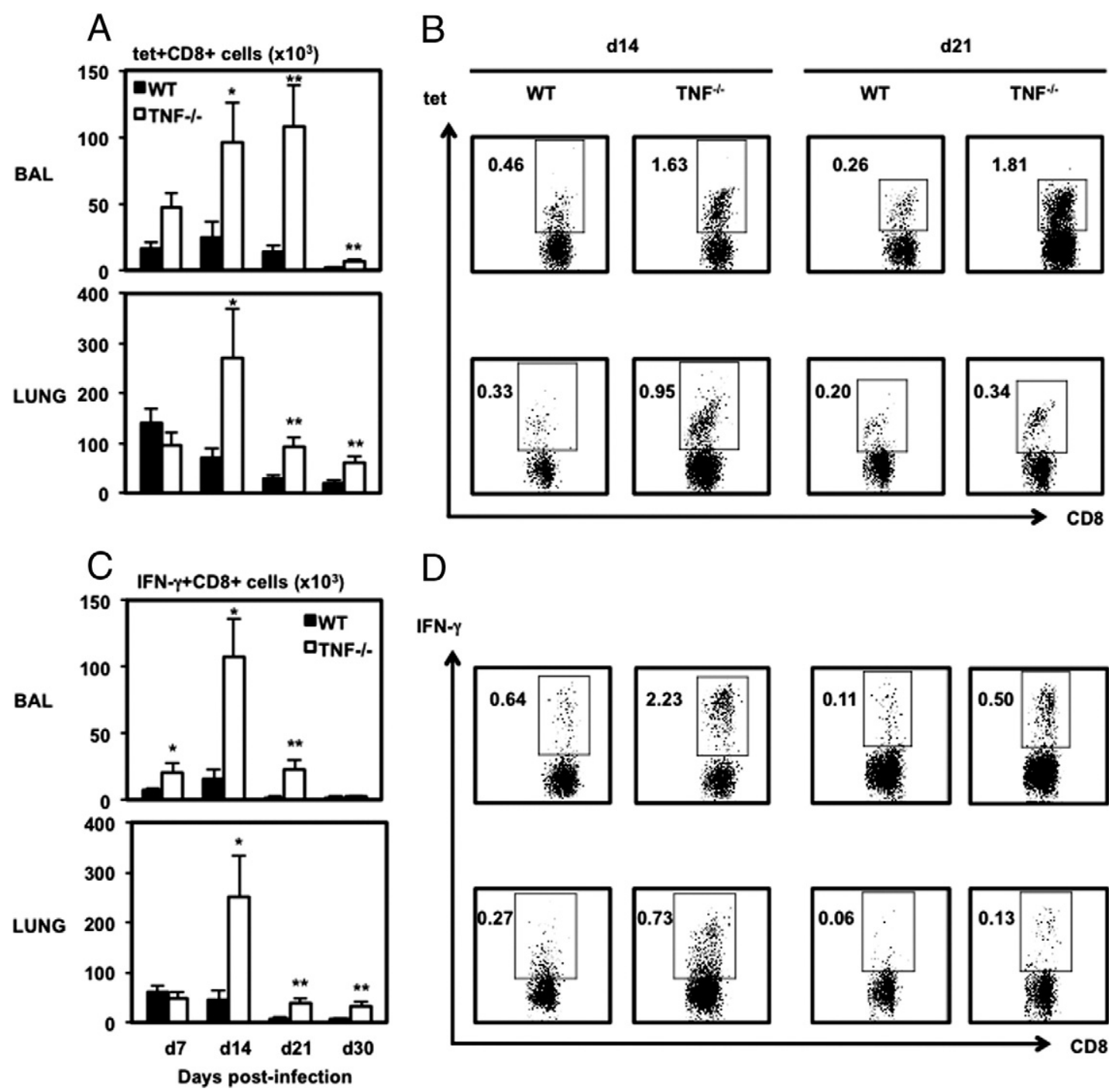

D

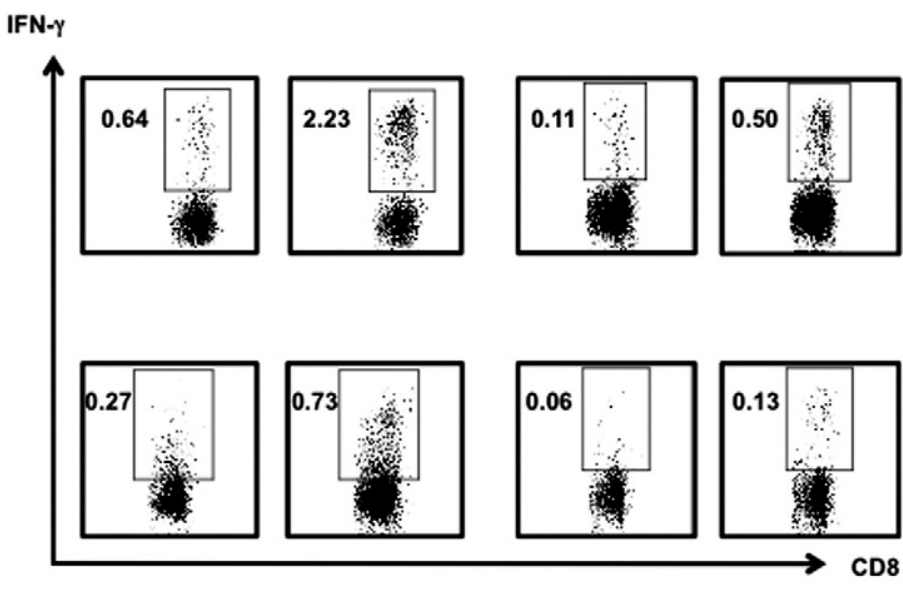

Figure 5. Flu antigen-specific CD8 T cells in the lungs following influenza infection. WT and $T N F^{-1-}$ mice were sacrificed $7,14,21$, and 30 days after influenza infection. A and B: Cells from the BAL and lung were stained with DbNP366 tetramers and analyzed by flow cytometry for NP366-specific tet ${ }^{+} \mathrm{CD} 8^{+} \mathrm{T}$ cells. $\mathbf{C}$ and D: Cells from the BAL and lung were stimulated with the NP366-374 influenza peptide, stained for intracellular IFN- $\gamma$, and analyzed by flow cytometry for antigen-specific IFN- $\gamma^{+} \mathrm{CD} 8^{+} \mathrm{T}$ cells. The charts represent total numbers of tet ${ }^{+} \mathrm{CD} 8^{+}$or IFN- $\gamma^{+} \mathrm{CD} 8^{+} \mathrm{T}$ cells in the BAL or lung at each time point. The dot plots show representative populations from the BAL and lung at 14 and 21 days after infection (gates show frequency of total cells). Data are expressed as mean \pm SEM ( $n=8$ to $12 /$ strain/time point from two to three independent experiments). ${ }^{*} P<0.05,{ }^{* * *} P<0.01$ as compared to WT controls. 
A

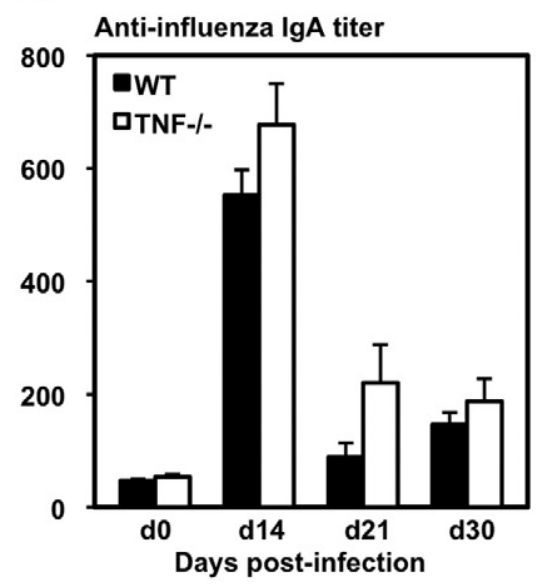

B

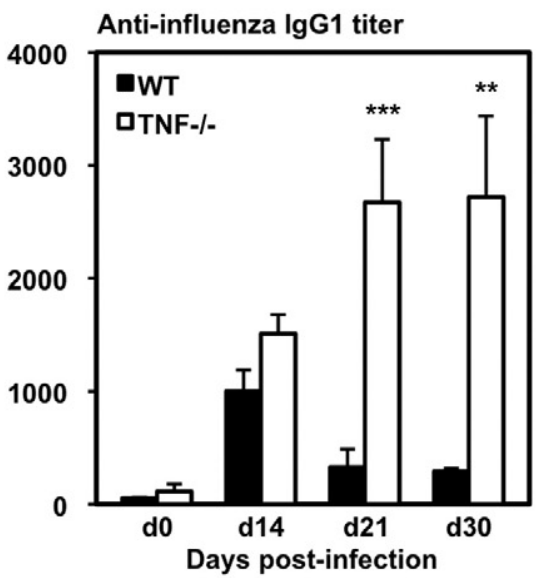

C

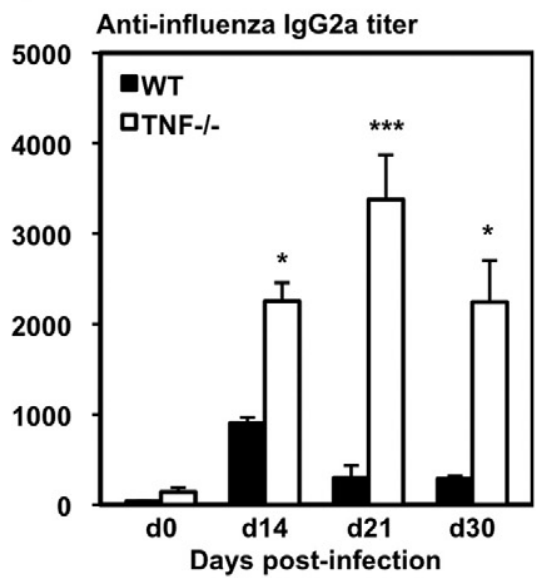

Figure 6. Flu antigen-specific antibody responses in the lungs following influenza infection. WT and TNF ${ }^{/-}$mice were sacrificed before infection (d0), as well as 14, 21, and 30 days after influenza infection. IgA (A), IgG1 (B), and IgG2a (C) levels in the BAL fluids were measured by ELISA. Data are expressed as mean $\pm \operatorname{SEM}\left(n=8\right.$ to $10 /$ strain/time point from two independent experiments). ${ }^{*} P<0.05,{ }^{* * *} P<0.01,{ }^{* * * * *} P<0.001$ as compared to WT controls.

and 21 days after infection in the BAL of $T N^{-/-}$mice than in WT mice (Figure 6A). However, the levels of influenza-specific IgG1 and IgG2a were generally much higher at days 14,21 , and 30 after infection in the BAL of $\mathrm{TNF}^{-1-}$ mice than in WT mice (Figure 6, B and C). Of note, the titers of IgG1 and IgG2a in the lung of WT mice declined sharply after day 14 , whereas they continued to rise and remained high in the lung of $T N^{-1-}$ mice after day 14 (Figure 6, B and C). In comparison, both infected WT and TNF ${ }^{-1-}$ mice had, by and large, comparable circulating levels of influenza-specific IgG1 and IgG2a (data not shown). These results show that consistent with heightened anti-influenza T-cell responses seen in the lung of influenza-infected $T N^{-\prime-}$ hosts, there were also heightened humoral immune responses.

\section{Dysregulated Proinflammatory Cytokine and Chemokine Responses in the Lung of Influenza- Infected TNF- $\alpha$-Deficient Hosts}

To investigate the potential molecular mechanisms of severe inflammatory cellular responses and immunopathology in the lung of influenza-infected $T N^{-\prime-}$ mice, we examined the level of proinflammatory cytokines in the lung. Although IFN- $\gamma$ levels were similar initially in the BAL of both WT and $\mathrm{TNF}^{-1-}$ mice at day 3 after infection, they were significantly higher in the lung of $\mathrm{TNF}^{-/-}$mice both at days 7 and 14 (Table 2). We also elected to examine the levels of $\mathrm{IL}-17$, which is known to play an important role in triggering both $\mathrm{CXC}$ and $\mathrm{CC}$ chemokine responses in the lung. ${ }^{53}$ There were relatively small, detectable levels of IL-17 in the lung of WT mice at days 3 and 7 , which became undetectable after day 7 (Table 2). In contrast, the levels of IL-17 were much more elevated in the lung of $\mathrm{TNF}^{-1-}$ mice by day 3 and remained sustained between days 7 and 21 after infection (Table 2). In contrast to heightened IFN- $\gamma$ and IL-17 in the lung of $T N^{-/-}$hosts, the lung levels of IL- $1 \beta$ were comparable between WT and $T N F^{-1-}$ mice (Table 2). We also measured the levels of anti-inflammatory cytokine IL-10 and found comparably low levels of this cytokine in both strains of mice (Table 2)

Given significantly higher levels of $\mathrm{IL}-17$ responses in the lung of infected $T N F^{-1-}$ mice beginning from day 3 after infection, we next examined the levels of chemokines including MCP-1 (CCL2), IP-10 (CXCL10), and KC $(\mathrm{CXCL} 1)$ in the lung. We found that these chemokines were highly inducible in the lung of both strains of mice on influenza infection and peaked between days 3 and 7 (Figure 7, A, B, and C). However, the levels of MCP-1 and IP-10 were significantly higher around 7 days after infec-

Table 2. Cytokine and Chemokine Expression in the Lung during Influenza Infection $(\mathrm{pg} / \mathrm{mL})$

\begin{tabular}{|c|c|c|c|c|c|c|c|c|}
\hline & \multicolumn{2}{|c|}{ Day 3} & \multicolumn{2}{|c|}{ Day 7} & \multicolumn{2}{|c|}{ Day 14} & \multicolumn{2}{|c|}{ Day 21} \\
\hline & WT & $T N F^{-1-}$ & WT & $T N F^{-1-}$ & WT & $T N F^{-1-}$ & WT & $T N F^{-1-}$ \\
\hline IFN- $\gamma$ * & $58.1 \pm 0.3$ & $58.4 \pm 0.6$ & $51.4 \pm 1.1$ & $180 \pm 81$ & $56.8 \pm 0.9$ & $116.0 \pm .7$ & $40.3 \pm 5.5$ & $43.6 \pm 5.6$ \\
\hline IL-17 & $2.1 \pm 2.1$ & $41.5 \pm 12.6$ & $20.2 \pm 5.2$ & $41.2 \pm 18.6$ & 0 & $5.4 \pm 5.4$ & 0 & $20.6 \pm 12.5$ \\
\hline $\mathrm{IL}-1 \beta$ & ND & ND & $20.1 \pm 2.4$ & $24.5 \pm 2.4$ & $17.9 \pm 0.9$ & $15.0 \pm 0.8$ & $21.7 \pm 0.5$ & $18.6 \pm 1.7$ \\
\hline IL-10 & ND & ND & $7.6 \pm 1.9$ & $12.8 \pm 1.4$ & $7.2 \pm 0.2$ & $6.3 \pm 0.4$ & $9.9 \pm 1.0$ & $13.8 \pm 3.1$ \\
\hline
\end{tabular}

Results are expressed as mean \pm SEM ( $n=4$ /strain/timepoint from one to two independent experiments).

*ELISA (all others Luminex).

$\mathrm{ND}$, not determined. 
A

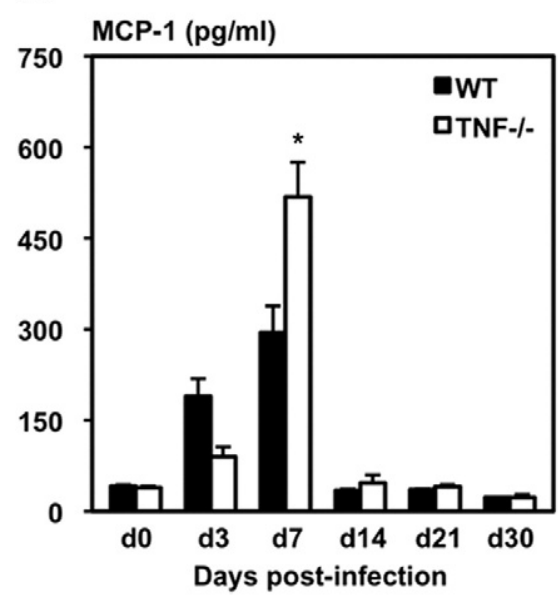

C

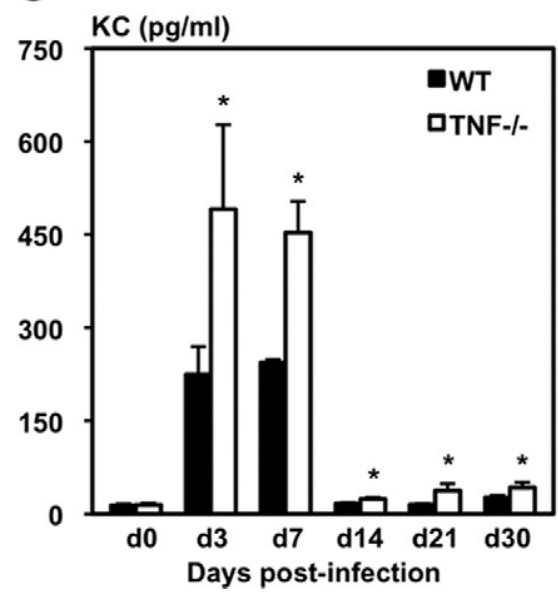

B

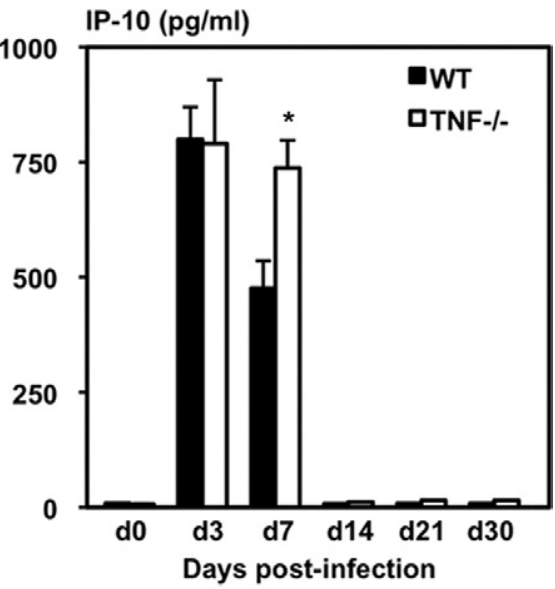

D

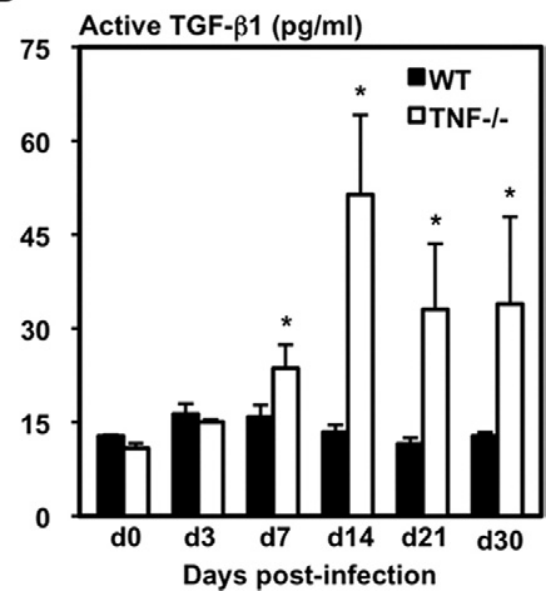

Figure 7. Levels of chemokines and fibrogenic growth factor in the lungs following influenza infection. WT and $T N F^{-1}$ mice were sacrificed at different time points after influenza infection. Levels of MCP-1 (A), IP-10 (B), and KC (C) were measured in the BAL fluid by Luminex. D: Active TGF- $\beta 1$ was measured by ELISA. Data are expressed as mean \pm SEM $(n=4$ to $8 /$ strain $/$ time point from two independent experiments). ${ }^{*} P<$ 0.05 as compared to WT controls. tion in the lung of $\mathrm{TNF}^{-/-}$mice than in WT controls (Figure $7, A$ and $B$ ), whereas the levels of $\mathrm{KC}$ were significantly higher at all time points examined in the lung of infected $T N^{-1-}$ mice, with the largest differences seen at 3 and 7 days after infection (Figure $7 \mathrm{C}$ ). Of note, the peak response of $\mathrm{CXC}$ neutrophil chemokine $\mathrm{KC}$ preceded that of MCP-1, a chemokine for monocytes/macrophages, T cells, and fibrocytes. ${ }^{54}$ Thus, earlier peak KC responses correlate with an early and transient nature of the neutrophilic response seen in the lung of influenzainfected $\mathrm{TNF}^{-/-}$hosts (Figure 4B). On the other hand, delayed peak MCP-1 responses correlate with relatively sustained mononuclear cellular responses (Figure 4, A and $\mathrm{C}$; Table 1) and immunopathology (Figure 2), and the subsequent development of fibrotic remodeling (Figures 2 and 3; Table 1) in the lung of influenza-infected $T N^{-1-}$ hosts.

On the basis of the documented association of MCP-1 to, and the critical role of, TGF- $\beta 1$ in tissue fibrogenesis, ${ }^{51,52,54-60}$ we examined the level of profibrogenic growth factor TGF- $\beta 1$. Indeed, we found that the levels of active TGF- $\beta 1$ in the lung of influenza-infected TNF ${ }^{-/-}$ mice were significantly higher than in WT control mice (Figure 7D), and the peak of MCP-1 responses (day 7) preceded the peak of TGF- $\beta 1$ responses seen at day 14 in the lung of influenza $\mathrm{TNF}^{-1-}$ mice (Figure 7A). Of importance, the elevated active TGF- $\beta 1$ responses were sustained between days 14 and 30 in the lung (Figure 7D) and correlated well with the development of fibrotic remodeling seen in the lung of influenza-infected $T N^{-\prime-}$ mice (Figures 2 and 3; Table 1). The above data together thus indicate a temporal relationship between dysregulated $\mathrm{MCP}-1$ responses and fibrotic tissue remodeling in the lung of $T N F^{-/-}$hosts following acute influenza infection.

\section{Attenuation of Lung Immunopathology in Influenza-Infected TNF- $\alpha$-Deficient Hosts by MCP-1 Depletion}

Compelling evidence suggests that MCP-1 is not only a chemokine for mononuclear cells, but of importance, it is also a profibrotic cytokine capable of direct up-regulation of TGF- $\beta 1$ expression ${ }^{55-61}$ and recruitment and induction of collagen synthesis by fibrocytes. ${ }^{51,62-68}$ Thus, given the dysregulated MCP-1 and its association with heightened TGF- $\beta 1$ production seen in influenza-infected

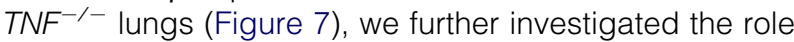
of MCP-1 in heightened immunopathology and fibrotic 
A

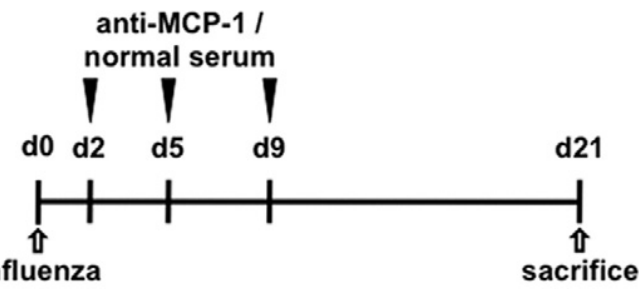

B normal serum

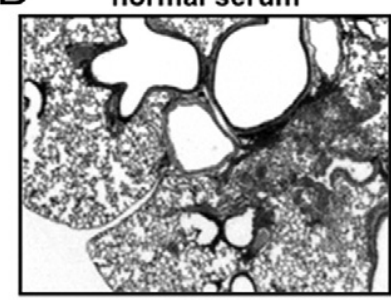

C \% lung parenchyma with immunopathology

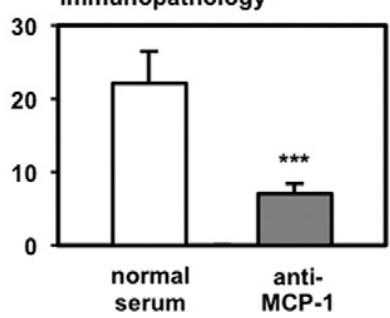

anti-MCP-1

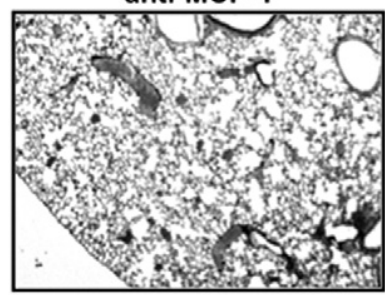
fibrosis

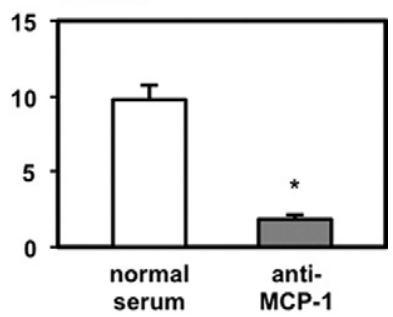

D \% lung parenchyma with

Figure 8. Modulation of lung immunopathology in the lungs of infected $T N F^{-1}$ mice by MCP-1 depletion. $T N F^{-1}$ mice were infected with influenza. A: On days 2, 5 , and 9 after infection, anti-MCP-1 serum or normal control rabbit serum was injected intraperitoneally, and mice were sacrificed on day 21. B: Lung tissue sections were stained with $\mathrm{H} \& \mathrm{E}$, and representative images are shown at $\times 5$ original magnification. C: Morphometric quantification of lung immunopathology performed on H\&E-stained sections. D: Morphometric quantification of lung fibrotic remodeling performed on Masson's trichrome-stained sections. Results are expressed as mean $\pm \operatorname{SEM}\left(n=8\right.$ to $13 /$ group from two independent experiments). ${ }^{*} P<0.05,{ }^{* * * * * *} P<$ 0.001 compared to normal serum-treated controls.

reaction in the lung of $\mathrm{TNF}^{-/-}$mice by means of $\mathrm{MCP}-1$ depletion. To this end, MCP-1 anti-serum (anti-MCP-1) or the control serum was administered intraperitoneally to $T \mathrm{NF}^{-1-}$ mice on days 2, 5, and 9 following influenza infection, and the mice were sacrificed at day 21 after infection for morphometric quantification of lung immunopathology and fibrotic remodeling (Figure 8A). MCP-1 depletion did not affect the rate of influenza viral clearance (data not shown). However, compared to the control group, depletion of MCP-1 resulted in significantly reduced inflammation and immunopathology as assessed on H\&E-stained tissue sections (Figure 8, B and C). Furthermore, it also significantly reduced the area of fibrotic reaction in the lung as assessed on Masson's trichromestained lung sections for collagen deposition (Figure 8D). Such potent attenuating effect by MCP-1 depletion on lung immunopathology in infected $\mathrm{TNF}^{-1-}$ animals contrasts with the modest effect exerted by CD8 T-cell depletion (data not shown).

We further examined the potential mechanisms by which MCP-1 depletion reduced lung immunopathology and fibrotic reactions in influenza-infected $T N F^{-1-}$ mice. We found that MCP-1 significantly reduced the number of $\mathrm{CD}_{11} \mathrm{~b}^{+}$and CD11c ${ }^{+}$macrophages/dendritic cells in the
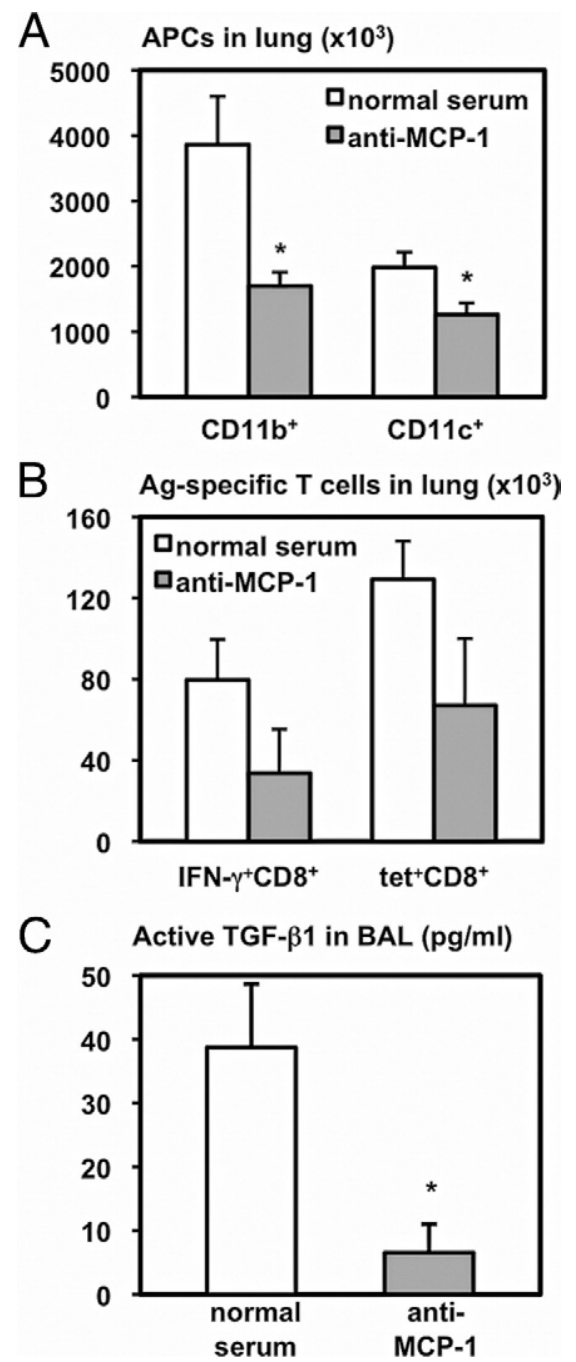

Figure 9. Modulation of immune cellular responses and active TGF- $\beta 1$ production in the lungs of infected $T N F^{-1}$ mice by $\mathrm{MCP}-1$ depletion. $\mathrm{TNF}^{-1-}$ mice were infected with influenza, and MCP-1 was depleted as in Figure 8A. At day 21 after infection, macrophages/dendritic cells (A) and influenza-specific $\mathrm{CD}^{+}{ }^{+} \mathrm{T}$ cells $(\mathbf{B})$ were enumerated in the lungs by flow cytometry. C: BAL fluids were analyzed for active TGF- $\beta 1$ by ELISA. Results are expressed as mean \pm SEM $\left(n=4\right.$ /group). ${ }^{*} P<0.05$ compared to normal serum-treated controls

lung (Figure 9A). It also decreased the number of influenza antigen-specific CD8 T cells (Figure 9B). There was also a significantly reduced level of fibrogenic growth factor TGF- $\beta 1$ in the lung by MCP- 1 depletion (Figure 9C). The above data together suggest that MCP-1 plays an important role in the development of severe immunopathology in the lung of influenza-infected $T N^{-1-}$ hosts.

\section{Worsening of Lung Immunopathology in Influenza-Infected Wild-Type Mice by Transgenic Expression of MCP-1}

To further understand the role of MCP-1 in immunopathology, we examined whether transient overexpression of MCP-1 in the lung of influenza-infected WT mice would worsen lung immunopathology. Thus, a recombinant rep- 
lication-defective adenoviral vector expressing murine MCP-1 gene (AdMCP-1) was delivered intranasally to the lungs of WT mice 1 day before influenza infection (Figure 10A). The control WT mice received Addl. The mice were sacrificed for analysis at day 21 after infection. MCP-1 gene transfer to the lung led to much greater lung immunopathology compared to influenza-infected control mice (Figure 10B). This was accompanied by significantly increased numbers of influenza NP-specific IFN$\gamma^{+} \mathrm{CD}^{+}$and tetramer ${ }^{+} \mathrm{CD}^{+} \mathrm{T}$ cells (Figure 10C). These results further support our conclusion that MCP-1 is one of the key cytokines involved in influenza-associated lung immunopathology.

\section{Enhanced Lung Immunopathology in Influenza- Infected Wild-Type Mice Depleted of TNF- $\alpha$}

We have shown that following influenza infection, TNF- $\alpha$ was up-regulated on days 3,7 , and 14 in the lungs of WT mice (see Supplemental Figure S1 at http://ajp.amjpathol. org) and have identified the critical regulatory role of TNF- $\alpha$ in influenza immunopathology and immune responses by using mice genetically deficient for TNF- $\alpha$. To verify the phenotype seen in influenza-infected TNF- $\alpha-$ deficient mice, we examined the effects of TNF- $\alpha$ deple-

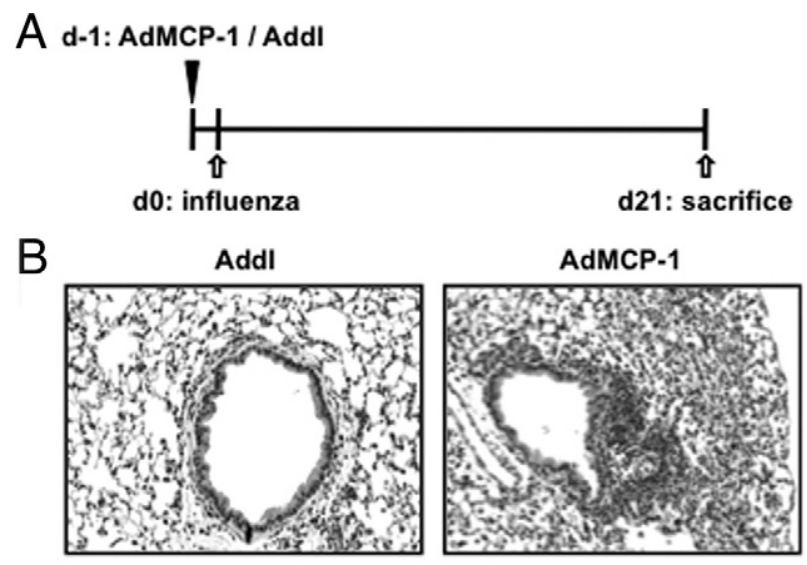

C

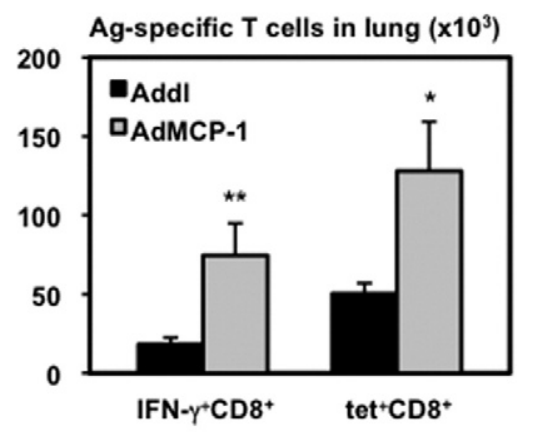

Figure 10. Enhancement of lung immunopathology in the lungs of infected WT mice by transgenic MCP-1 overexpression. A: WT mice were infected intranasally with Addl or AdMCP-1, the next day infected with influenza, and sacrificed on day 21. B: Lung tissue sections were stained with H\&E, and representative images are shown at $\times 5$ original magnification. C: Influenzaspecific $\mathrm{CD}^{+} \mathrm{T}$ cells were enumerated in the lungs with flow cytometry. Results are expressed as mean $\pm \operatorname{SEM}\left(n=4\right.$ to 5 /group). ${ }^{*} P<0.05$, ${ }^{* * *} P<$ 0.005 compared to Addl-treated control mice. tion in WT mice following influenza infection. To this end, TNF- $\alpha$ anti-serum (anti-TNF- $\alpha$ ) or control serum was administered intraperitoneally to WT mice repeatedly on days $-1,2,5,8,12$, and 15 following influenza infection, and the mice were sacrificed at day 21 (see Supplemental Figure S2A at http://ajp.amjpathol.org). Compared to the control group, depletion of TNF- $\alpha$ in WT mice indeed resulted in markedly increased immunopathology in H\&E-stained sections (see Supplemental Figure S2B at http://ajp.amjpathol.org) and fibrotic remodeling by Masson's trichrome staining (data not shown). Also, significantly increased numbers of influenza antigen-specific CD8 T cells were seen in the lung (see Supplemental Figure S2, C and D, at $h t t p: / /$ ajp.amjpathol.org). These results further support the critical role of TNF- $\alpha$ in controlling the level of immune activation and lung immunopathology following influenza infection.

\section{Discussion}

Severe lung immunopathology is known to be one of the main causes of influenza-related morbidity and mortality. ${ }^{3-11}$ TNF- $\alpha$, a classical proinflammatory cytokine, has recently been shown to play anti-inflammatory and antifibrotic roles in various models. ${ }^{32-43}$ However, whether TNF- $\alpha$ plays an immunoregulatory role during influenza infection remains unclear. Using a mouse model of respiratory influenza infection, we investigated this issue. We show that TNF- $\alpha$ is not required for influenza viral clearance, but it is required for controlling the level of antiinfluenza inflammatory and immune responses. Thus, dysregulated anti-influenza inflammatory responses resulting from the genetic deficiency or antibody-mediated depletion of TNF- $\alpha$ lead to illness associated with severe immunopathology and tissue fibrotic remodeling in the lung. We further identify that the dysregulated MCP-1 response represents an important molecular mechanism in heightened immunopathology. Our study thus establishes that although it is dispensable in influenza viral clearance, TNF- $\alpha$ is critically required for controlling immunopathology and aberrant tissue repair in the course of acute influenza infection.

Transient lung inflammation was observed in WT lungs between 3 and 14 days following infection, which decreased thereafter as lungs returned to normal by 21 days. In sharp contrast, the lung immunopathology was much more severe and sustained in $T_{N F^{-1}}$ lungs throughout the infection. At day 7 , there was increased cellular infiltration, degeneration, and exfoliation of the airway epithelium and edema in $T N^{-/-}$lungs. After the virus was completely cleared at 14 days, TNF $^{-\prime-}$ lungs showed more extensive necrotizing injury, edema, and cellular infiltration into the airways. By day 21 after infection, when WT lungs returned back to normal, TNF $^{-/-}$ lungs continued to worsen, showing a loss of clear alveolar structure, hemorrhaging, and epithelial metaplasia, which sustained even out to 30 days after infection. Associated with the heightened immunopathology observed in the lung of influenza-infected $T N F^{-/-}$hosts is 
fibrotic tissue remodeling. The fibrotic lesion seen in these mice began from 14 days after infection and is characterized by the appearance of fibrotic foci containing $\alpha$-SMA-expressing myofibroblasts and collagen deposition. The antifibrotic role of TNF- $\alpha$ was also previously seen in models of idiopathic pulmonary fibrosis, ureteral obstruction, and scleroderma. ${ }^{41-43}$ It is noteworthy that much of the previous evidence to suggest a proinflammatory or proimmune role of TNF- $\alpha$ in anti-influenza host defense is drawn from in vitro studies ${ }^{23,24,29}$ or deduced from the historical belief of its proinflammatory nature. To our knowledge, there have been only few direct in vivo investigations on the role of TNF- $\alpha$ in influenza immunopathology. One study shows the involvement of CD8 Tcell-derived TNF- $\alpha$ in causing bronchial epithelial injury. ${ }^{28}$ The opposing conclusions regarding the role of TNF- $\alpha$ in influenza immunopathology drawn from this study and our current study are likely because the former used an adoptive transgenic T-cell transfer approach and a transgenic mouse model in which the bronchial epithelial cells overexpress hemagglutinin. ${ }^{28}$ Two other studies have shown a decrease in disease severity in TNFR1 knockout mice infected with highly virulent H5N1 avian or a reconstructed 1918 pandemic influenza virus. In agreement with our study, these studies report the lack of involvement of TNFR1 in influenza viral clearance. ${ }^{26,27}$ However, infected TNFR1-deficient mice had a significant delay in weight loss compared to WT from day 3 to 8 after infection, although they ultimately succumbed. ${ }^{26,27}$ On one hand, these findings lend further support to the current belief that TNF- $\alpha$ is a proimmune or proinflammatory cytokine, particularly in the early response (first 7 days of infection) and that a "cytokine storm" may contribute to disease severity. ${ }^{23-25}$ On the other hand, these findings differ from our current results with respect to the role of TNF- $\alpha$ in influenza disease severity and immunopathology, which is likely due to the choice of model influenza viruses of different pathogenicity. In support, use of a less virulent strain of H5N1 in the same study did not lead to significant differences in weight loss or disease outcome. ${ }^{26}$ The choice of a mouse-adapted strain of influenza virus with relatively low virulence in our current study was to allow us to study the role of TNF- $\alpha$ at later phases of influenza, when the immune system is required to return to homeostasis. Thus, although the earlier studies suggest a proinflammatory role of TNF- $\alpha$ in anti-influenza host defense, our current investigation suggests that proinflammatory molecules other than TNF- $\alpha$ induced by influenza could replace the proinflammatory activities by TNF- $\alpha$ in the early course of influenza infection, which explains the unimpaired influenza viral clearance in $\mathrm{TNF}^{-\prime-}$ hosts that we and others have observed. Our observation that TNF- $\alpha$ deficiency leads to severe immunopathology and tissue remodeling strongly suggests that the immunoregulatory function of this cytokine is indispensable, particularly when influenza viral clearance is near completion and lung homeostasis needs to be restored at later phases of infection. On the basis of previous and our current findings, we argue that TNF- $\alpha$ plays a differential and biphasic role during the course of primary influenza infection. In the early phase of infection, it is proinflammatory and may contribute to disease severity, particularly in cases of highly pathogenic influenza, but it is immunoregulatory in later phases of infection after viral clearance. Overall, our study thus lends strong support to the recent emerging conviction that TNF- $\alpha$ is a double-edged sword, and besides its proinflammatory properties, it plays an important immunoregulatory function in the host response to a number of intracellular infections and autoimmunogens. ${ }^{21,22,32-40}$

In our current study, we have found TNF- $\alpha$ regulation of MCP-1 responses to be an important molecular mechanism by which TNF- $\alpha$ negatively controls the level of influenza immunopathology. MCP-1 has previously been reported to be a major profibrotic chemokine involved in various fibrotic processes, including recruitment of fibrocytes, induction of collagen synthesis, and up-regulation of TGF- $\beta 1$ expression in various models. ${ }^{50,51,55-61,63-68}$ Indeed, we observed that MCP-1 responses preceded the responses of fibrogenic growth factor TGF- $\beta 1,{ }^{51,52}$ which were significantly higher in the lung of infected $T N F^{-\prime-}$ lungs and were well correlated with fibrotic tissue remodeling seen in $\mathrm{TNF}^{-/}$lungs at later time points during influenza infection. Thus, depletion of MCP-1 in influenza-infected $T N F^{-\prime-}$ hosts markedly reduced lung immunopathology and tissue remodeling, and such MCP-1 depletion-improved welfare was associated with diminished production of bioactive TGF- $\beta 1$. On the other hand, by using a transient gene transfer approach, we observed that transgenic MCP-1 overexpression in infected WT mouse lungs markedly increased influenzaassociated immunopathology and tissue injury. Our observations together suggest an influenza-TNF- $\alpha-$ MCP-1TGF- $\beta$ 1-immunopathology axis. It is likely that in addition to its fibrogenic property, MCP-1 also contributes to tissue immunopathology via its robust effects on inflammatory cells including macrophages and monocytes. Excessive accumulation of these inflammatory cells in the lung contributes to severe immunopathology and tissue injury

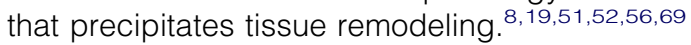

The dysregulated anti-influenza T-cell responses that we observed in infected $\mathrm{TNF}^{-1-}$ or TNF-depleted hosts are likely due in part to reduced T-cell contraction following viral clearance. These results are consistent with studies of intracellular mycobacterial and LCMV infections. Indeed, it has been previously shown that during mycobacterial infection, TNF- $\alpha$ deficiency results in uncontrolled T-cell proliferation and immune activation, and massive lung immunopathology. ${ }^{32}$ Furthermore, lack of TNF- $\alpha$ leads to dysregulated CD4 and CD8 T-cell expansion and a prolonged T-cell effector phase following LCMV infection. ${ }^{33-35}$ In addition, Turner and colleagues have suggested a role of TNFR2 in editing CD8 T cells following PR8 infection. ${ }^{70}$ Thus, it is likely that heightened helper T cells, as well as decreased B-cell apoptosis ${ }^{71}$ resulting from TNF- $\alpha$ deficiency, leads to the increased anti-influenza humoral responses that we have also observed in our current study. Of interest, we found that depletion of CD8 T cells in influenza-infected $T_{N F^{-\prime-}}$ animals around the time of viral clearance had only a modest improving effect on lung immunopathology (data not shown). First, this suggests a complex role played by 
anti-influenza T cells and the difficulty of determining the right timing for T-cell depletion, as these cells are critical to viral clearance. Second, the much-heightened lung immunopathology in influenza-infected $T_{N F^{-\prime-}}$ animals may involve multiple inflammatory cell subsets including macrophages and monocytes. This contention is strongly supported by our findings that compared to T-cell depletion, MCP-1 depletion proved to be a much more effective way to attenuate the severe immunopathology seen in the lung of infected $T N F^{-\prime-}$ hosts.

In conclusion, our results indicate that TNF- $\alpha$ is dispensable for influenza viral clearance. However, this cytokine is critically required for controlling the extent of influenza immunopathology and tissue injury. Thus, lack of TNF- $\alpha$ results in dysregulated inflammatory responses and tissue immunopathology. As TNF- $\alpha$ depletion has been widely implemented as a means to counter inflammatory conditions in humans, ${ }^{21,36-40}$ our results caution the clinical use of anti-TNF- $\alpha$ therapeutics, which may potentially worsen influenza-associated immunopathology in the lung, particularly during flu seasons or epidemics.

\section{Acknowledgments}

We thank Dr. Mangalakumari Jeyanathan and Christopher R. Shaler for helpful comments, Dr. Dominik K. Fritz for help with morphometric analysis, and Xueya Feng and Susanna Goncharova for technical assistance.

\section{References}

1. Doherty PC, Turner SJ, Webby RG, Thomas PG: Influenza and the challenge for immunology. Nat Immunol 2006, 7:449-455

2. Michaelis M, Doerr HW, Cinatl J Jr: Novel swine-origin influenza $A$ virus in humans: another pandemic knocking at the door. Med Microbiol Immunol 2009, 198:175-183

3. Zhao C, Gan Y, Sun J: Radiographic study of severe Influenza-A (H1N1) disease in children, Eur J Radiol 2011, 79:447-451

4. Harms PW, Schmidt LA, Smith LB, Newton DW, Pletneva MA, Walters LL, Tomlins SA, Fisher-Hubbard A, Napolitano LM, Park PK, Blaivas M, Fantone J, Myers JL, Jentzen JM: Autopsy findings in eight patients with fatal H1N1 influenza. Am J Clin Pathol 2010, 134:27-35

5. To KF, Chan PK, Chan KF, Lee WK, Lam WY, Wong KF, Tang NL, Tsang DN, Sung RY, Buckley TA, Tam JS, Cheng AF: Pathology of fatal human infection associated with avian influenza A H5N1 virus. J Med Virol 2001, 63:242-246

6. Qiao J, Zhang M, Bi J, Wang X, Deng G, He G, Luan Z, Lv N, Xu T, Zhao L: Pulmonary fibrosis induced by H5N1 viral infection in mice. Respir Res 2009, 10:107

7. Taubenberger JK, Morens DM: The pathology of influenza virus infections. Annu Rev Pathol 2008, 3:499-522

8. La Gruta NL, Kedzierska K, Stambas J, Doherty PC: A question of self-preservation: immunopathology in influenza virus infection. Immunol Cell Biol 2007, 85:85-92

9. Peiris JS, Cheung CY, Leung CY, Nicholls JM: Innate immune responses to influenza A H5N1: friend or foe?. Trends Immunol 2009, 30:574-584

10. Peiris JS, Hui KP, Yen HL: Host response to influenza virus: protection versus immunopathology. Curr Opin Immunol 2010, 22:475-481

11. Naik PK, Moore BB: Viral infection and aging as cofactors for the development of pulmonary fibrosis. Expert Rev Respir Med 2010, 4:759-771

12. Tamura S, Kurata T: Defense mechanisms against influenza virus infection in the respiratory tract mucosa. Jpn J Infect Dis 2004, $57: 236-247$
13. Brown DM, Roman E, Swain SL: CD4 T cell responses to influenza infection. Semin Immunol 2004, 16:171-177

14. Woodland DL, Randall TD: Anatomical features of anti-viral immunity in the respiratory tract. Semin Immunol 2004, 16:163-170

15. Van Reeth K: Cytokines in the pathogenesis of influenza. Vet Microbiol 2000, 74:109-116

16. Julkunen I, Sareneva T, Pirhonen J, Ronni T, Melen K, Matikainen S: Molecular pathogenesis of influenza A virus infection and virus-induced regulation of cytokine gene expression. Cytokine Growth Factor Rev 2001, 12:171-180

17. Strieter RM, Gomperts BN, Keane MP: The role of CXC chemokines in pulmonary fibrosis. J Clin Invest 2007, 117:549-556

18. Enelow RI, Mohammed AZ, Stoler MH, Liu AN, Young JS, Lou YH, Braciale TJ: Structural and functional consequences of alveolar cell recognition by $\mathrm{CD} 8(+) \mathrm{T}$ lymphocytes in experimental lung disease. J Clin Invest 1998, 102:1653-1661

19. Lin KL, Suzuki Y, Nakano H, Ramsburg E, Gunn MD: CCR2+ monocyte-derived dendritic cells and exudate macrophages produce influenza-induced pulmonary immune pathology and mortality. J Immunol 2008, 180:2562-2572

20. Snelgrove RJ, Goulding J, Didierlaurent AM, Lyonga D, Vekaria S, Edwards L, Gwyer E, Sedgwick JD, Barclay AN, Hussell T: A critical function for CD200 in lung immune homeostasis and the severity of influenza infection. Nat Immunol 2008, 9:1074-1083

21. Aggarwal BB: Signalling pathways of the TNF superfamily: a doubleedged sword. Nat Rev Immunol 2003, 3:745-756

22. Hehlgans T, Pfeffer K: The intriguing biology of the tumour necrosis factor/tumour necrosis factor receptor superfamily: players, rules and the games. Immunology 2005, 115:1-20

23. Matikainen S, Siren J, Tissari J, Veckman V, Pirhonen J, Severa M, Sun Q, Lin R, Meri S, Uze G, Hiscott J, Julkunen I: Tumor necrosis factor alpha enhances influenza A virus-induced expression of antiviral cytokines by activating RIG-I gene expression. J Virol 2006, 80:3515-3522

24. Herold S, von Wulffen W, Steinmueller M, Pleschka S, Kuziel WA, Mack M, Srivastava M, Seeger W, Maus UA, Lohmeyer J: Alveolar epithelial cells direct monocyte transepithelial migration upon influenza virus infection: impact of chemokines and adhesion molecules. J Immunol 2006, 177:1817-1824

25. Richter MV, Topham DJ: The alpha1beta1 integrin and TNF receptor II protect airway CD8+ effector T cells from apoptosis during influenza infection. J Immunol 2007, 179:5054-5063

26. Szretter KJ, Gangappa S, Lu X, Smith C, Shieh WJ, Zaki SR, Sambhara S, Tumpey TM, Katz JM: Role of host cytokine responses in the pathogenesis of avian H5N1 influenza viruses in mice. J Virol 2007, 81:2736-2744

27. Belisle SE, Tisoncik JR, Korth MJ, Carter VS, Proll SC, Swayne DE, Pantin-Jackwood M, Tumpey TM, Katze MG: Genomic profiling of tumor necrosis factor alpha (TNF-alpha) receptor and interleukin-1 receptor knockout mice reveals a link between TNF-alpha signaling and increased severity of 1918 pandemic influenza virus infection. J Virol 2010, 84:12576-12588

28. Xu L, Yoon H, Zhao MQ, Liu J, Ramana CV, Enelow RI: Cutting edge: pulmonary immunopathology mediated by antigen-specific expression of TNF-alpha by antiviral CD8+ T cells. J Immunol 2004, 173:721-725

29. Liu AN, Mohammed AZ, Rice WR, Fiedeldey DT, Liebermann JS Whitsett JA, Braciale TJ, Enelow RI: Perforin-independent CD8(+) T-cell-mediated cytotoxicity of alveolar epithelial cells is preferentially mediated by tumor necrosis factor-alpha: relative insensitivity to Fas ligand. Am J Respir Cell Mol Biol 1999, 20:849-858

30. Kasahara S, Ando K, Saito K, Sekikawa K, Ito H, Ishikawa T, Ohnishi $\mathrm{H}$, Seishima M, Kakumu S, Moriwaki H: Lack of tumor necrosis factor alpha induces impaired proliferation of hepatitis B virus-specific cytotoxic T Iymphocytes. J Virol 2003, 77:2469-2476

31. Trevejo JM, Marino MW, Philpott N, Josien R, Richards EC, Elkon KB, Falck-Pedersen E: TNF-alpha -dependent maturation of local dendritic cells is critical for activating the adaptive immune response to virus infection, Proc Natl Acad Sci U S A 2001, 98:12162-12167

32. Zganiacz A, Santosuosso M, Wang J, Yang T, Chen L, Anzulovic M, Alexander S, Gicquel B, Wan Y, Bramson J, Inman M, Xing Z: TNF-alpha is a critical negative regulator of type 1 immune activation during intracellular bacterial infection. J Clin Invest 2004, 113:401-413 
33. Suresh M, Singh A, Fischer C: Role of tumor necrosis factor receptors in regulating CD8 T-cell responses during acute lymphocytic choriomeningitis virus infection. J Virol 2005, 79:202-213

34. Singh $A$, Wuthrich $M$, Klein $B$, Suresh $M$ : Indirect regulation of CD4 T-cell responses by tumor necrosis factor receptors in an acute viral infection. J Virol 2007, 81:6502-6512

35. Singh $A$, Suresh $M$ : A role for TNF in limiting the duration of CTL effector phase and magnitude of CD8 T cell memory. J Leukoc Biol 2007, 82:1201-1211

36. McDevitt $\mathrm{H}$, Munson S, Ettinger R, Wu A: Multiple roles for tumor necrosis factor-alpha and lymphotoxin alpha/beta in immunity and autoimmunity. Arthritis Res 2002, 4 Suppl 3:S141-S152

37. Kassiotis G, Kollias G: Uncoupling the proinflammatory from the immunosuppressive properties of tumor necrosis factor (TNF) at the p55 TNF receptor level: implications for pathogenesis and therapy of autoimmune demyelination. J Exp Med 2001, 193:427-434

38. Campbell IK, O'Donnell K, Lawlor KE, Wicks IP: Severe inflammatory arthritis and lymphadenopathy in the absence of TNF. J Clin Invest 2001, 107:1519-1527

39. van Oosten BW, Barkhof F, Truyen L, Boringa JB, Bertelsmann FW, von Blomberg BM, Woody JN, Hartung HP, Polman $\mathrm{CH}$ : Increased $\mathrm{MRI}$ activity and immune activation in two multiple sclerosis patients treated with the monoclonal anti-tumor necrosis factor antibody cA2. Neurology 1996, 47:1531-1534

40. Berg L, Lampa J, Rogberg S, van Vollenhoven R, Klareskog L: Increased peripheral $\mathrm{T}$ cell reactivity to microbial antigens and collagen type II in rheumatoid arthritis after treatment with soluble TNFalpha receptors. Ann Rheum Dis 2001, 60:133-139

41. Frankel SK, Cosgrove GP, Cha SI, Cool CD, Wynes MW, Edelman BL, Brown KK, Riches DW: TNF-alpha sensitizes normal and fibrotic human lung fibroblasts to Fas-induced apoptosis. Am J Respir Cell Mol Biol 2006, 34:293-304

42. Morimoto Y, Gai Z, Tanishima H, Kawakatsu M, Itoh S, Hatamura I, Muragaki Y: TNF-alpha deficiency accelerates renal tubular interstitia fibrosis in the late stage of ureteral obstruction. Exp Mol Pathol 2008, 85:207-213

43. Askew D, Zhou L, Wu C, Chen G, Gilliam AC: Absence of cutaneous TNFalpha-producing CD4+ T cells and TNFalpha may allow for fibrosis rather than epithelial cytotoxicity in murine sclerodermatous graft-versus-host disease, a model for human scleroderma. J Invest Dermatol 2007, 127:1905-1914

44. Brown EG, Bailly JE: Genetic analysis of mouse-adapted influenza A virus identifies roles for the NA. PB1, and PB2 genes in virulence, Virus Res 1999, 61:63-76

45. Small CL, Shaler CR, McCormick S, Jeyanathan M, Damjanovic D, Brown EG, Arck P, Jordana M, Kaushic C, Ashkar AA, Xing Z: Influenza infection leads to increased susceptibility to subsequent bacterial superinfection by impairing NK cell responses in the lung $\mathrm{J}$ Immunol 2010, 184:2048-2056

46. Divangahi M, Yang T, Kugathasan K, McCormick S, Takenaka S, Gaschler G, Ashkar A, Stampfli M, Gauldie J, Bramson J, Takai T, Brown E, Yokoyama WM, Aoki N, Xing Z: Critical negative regulation of type $1 \mathrm{~T}$ cell immunity and immunopathology by signaling adaptor DAP12 during intracellular infection. J Immunol 2007, 179:4015-4026

47. Xing Z, Tremblay GM, Sime PJ, Gauldie J: Overexpression of granulocyte-macrophage colony-stimulating factor induces pulmonary granulation tissue formation and fibrosis by induction of transforming growth factor-beta 1 and myofibroblast accumulation. Am J Pathol 1997, 150:59-66

48. Small CL, McCormick S, Gill N, Kugathasan K, Santosuosso M, Donaldson N, Heinrichs DE, Ashkar A, Xing Z: NK cells play a critical protective role in host defense against acute extracellular Staphylococcus aureus bacterial infection in the lung. J Immunol 2008, 180:5558-5568

49. Xing Z, Zganiacz A, Wang J, Divangahi M, Nawaz F: IL-12-independent Th1-type immune responses to respiratory viral infection: requirement of IL-18 for IFN-gamma release in the lung but not for the differentiation of viral-reactive Th1-type lymphocytes. J Immunol 2000, 164:2575-2584

50. Motomura Y, Khan WI, El-Sharkawy RT, Verma-Gandhu M, Verdu EF, Gauldie J, Collins SM: Induction of a fibrogenic response in mouse colon by overexpression of monocyte chemoattractant protein 1. Gut 2006, 55:662-670
51. Wynn TA: Cellular and molecular mechanisms of fibrosis. J Pathol 2008, 214:199-210

52. Ask K, Martin GE, Kolb M, Gauldie J: Targeting genes for treatment in idiopathic pulmonary fibrosis: challenges and opportunities, promises and pitfalls. Proc Am Thorac Soc 2006, 3:389-393

53. Kolls JK, Khader SA: The role of Th17 cytokines in primary mucosal immunity. Cytokine Growth Factor Rev 2010, 21:443-448

54. Coelho AL, Hogaboam CM, Kunkel SL: Chemokines provide the sustained inflammatory bridge between innate and acquired immunity. Cytokine Growth Factor Rev 2005, 16:553-560

55. McMillan TR, Moore BB, Weinberg JB, Vannella KM, Fields WB, Christensen PJ, van Dyk LF, Toews GB: Exacerbation of established pulmonary fibrosis in a murine model by gammaherpesvirus. Am J Respir Crit Care Med 2008, 177:771-780

56. Murray LA, Argentieri RL, Farrell FX, Bracht M, Sheng H, Whitaker B, Beck $H$, Tsui $P$, Cochlin K, Evanoff HL, Hogaboam CM, Das AM: Hyper-responsiveness of IPF/UIP fibroblasts: interplay between TGFbeta1, IL-13 and CCL2. Int J Biochem Cell Biol 2008, 40:2174-2182

57. Wilson MS, Wynn TA: Pulmonary fibrosis: pathogenesis, etiology and regulation. Mucosal Immunol 2009, 2:103-121

58. Rose CE Jr., Sung SS, Fu SM: Significant involvement of CCL2 (MCP-1) in inflammatory disorders of the lung. Microcirculation 2003, 10:273-288

59. Zhang K, Gharaee-Kermani M, Jones ML, Warren JS, Phan SH: Lung monocyte chemoattractant protein-1 gene expression in bleomycininduced pulmonary fibrosis. J Immunol 1994, 153:4733-4741

60. Moore BB, Kolodsick JE, Thannickal VJ, Cooke K, Moore TA, Hogaboam C, Wilke CA, Toews GB: CCR2-mediated recruitment of fibrocytes to the alveolar space after fibrotic injury. Am J Pathol 2005 , 166:675-684

61. Gharaee-Kermani M, Denholm EM, Phan SH: Costimulation of fibroblast collagen and transforming growth factor beta1 gene expression by monocyte chemoattractant protein-1 via specific receptors. J Bio Chem 1996, 271:17779-17784

62. Agostini C, Gurrieri C: Chemokine/cytokine cocktail in idiopathic pulmonary fibrosis. Proc Am Thorac Soc 2006, 3:357-363

63. Lloyd CM, Minto AW, Dorf ME, Proudfoot A, Wells TN, Salant DJ, Gutierrez-Ramos JC: RANTES and monocyte chemoattractant protein-1 (MCP-1) play an important role in the inflammatory phase of crescentic nephritis, but only MCP-1 is involved in crescent formation and interstitial fibrosis. J Exp Med 1997, 185:1371-1380

64. Belperio JA, Keane MP, Burdick MD, Lynch JP 3rd, Xue YY, Berlin A, Ross DJ, Kunkel SL, Charo IF, Strieter RM: Critical role for the chemokine MCP-1/CCR2 in the pathogenesis of bronchiolitis obliterans syndrome. J Clin Invest 2001, 108:547-556

65. Moore BB, Paine R 3rd, Christensen PJ, Moore TA, Sitterding S, Ngan R, Wilke CA, Kuziel WA, Toews GB: Protection from pulmonary fibrosis in the absence of CCR2 signaling. J Immunol 2001, 167:4368-4377

66. Gharaee-Kermani M, McCullumsmith RE, Charo IF, Kunkel SL, Phan $\mathrm{SH}$ : CC-chemokine receptor 2 required for bleomycin-induced pulmonary fibrosis. Cytokine 2003, 24:266-276

67. Okuma T, Terasaki Y, Kaikita K, Kobayashi H, Kuziel WA, Kawasuji M, Takeya M: C-C chemokine receptor 2 (CCR2) deficiency improves bleomycin-induced pulmonary fibrosis by attenuation of both macrophage infiltration and production of macrophage-derived matrix metalloproteinases. J Pathol 2004, 204:594-604

68. Inoshima I, Kuwano K, Hamada N, Hagimoto N, Yoshimi M, Maeyama T, Takeshita A, Kitamoto S, Egashira K, Hara N: Antimonocyte chemoattractant protein-1 gene therapy attenuates pulmonary fibrosis in mice. Am J Physiol Lung Cell Mol Physiol 2004 286:L1038-L1044

69. Blease K, Mehrad B, Lukacs NW, Kunkel SL, Standiford TJ, Hogaboam CM: Antifungal and airway remodeling roles for murine monocyte chemoattractant protein-1/CCL2 during pulmonary exposure to Asperigillus fumigatus conidia. J Immunol 2001, 166:1832-1842

70. Turner SJ, La Gruta NL, Stambas J, Diaz G, Doherty PC: Differential tumor necrosis factor receptor 2-mediated editing of virus-specific CD8+ effector T cells, Proc Natl Acad Sci U S A 2004, 101:3545-3550

71. Sedger LM, Hou S, Osvath SR, Glaccum MB, Peschon JJ, van Rooijen $\mathrm{N}$, Hyland L: Bone marrow B cell apoptosis during in vivo influenza virus infection requires TNF-alpha and lymphotoxin-alpha. J Immunol 2002, 169:6193-6201 